
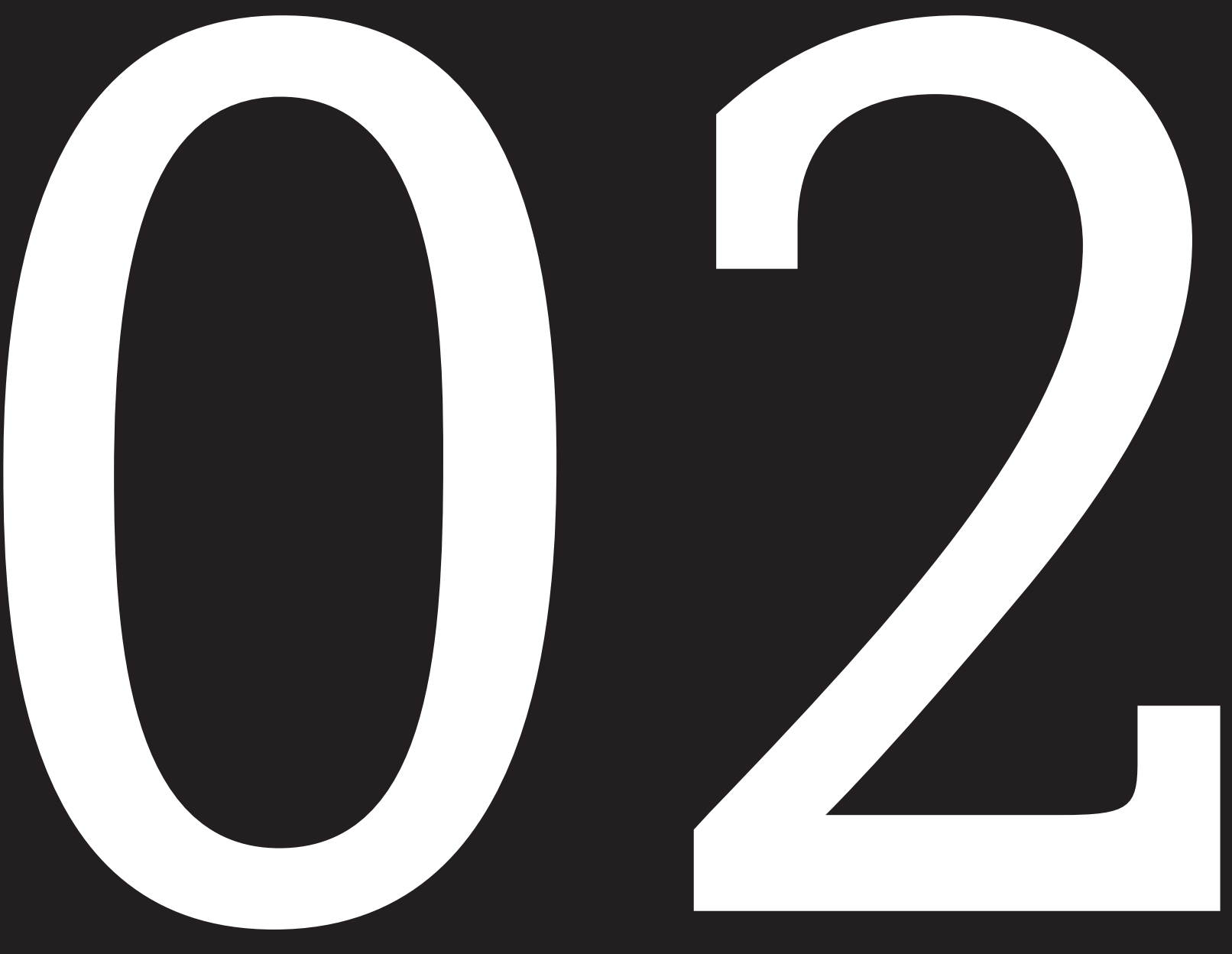

DOI: https://doi.org/10.14483/2422278X.13988 


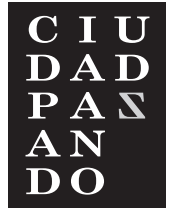

\title{
DOSSIER
}

Artículo de investigación

\section{Entramados cartográficos de las memorias familiares del semillero Incandescencias}

Cartographic lattices of the family memories of the "Incandescencias" seedbed

\author{
David Ramos Delgado ${ }^{1}$ \\ Colombia
}

\author{
Wendy Díaz Ortiz ${ }^{2}$ (iD \\ Colombia
}

\section{Sharon Benitez Pardo ${ }^{3}$ \\ Colombia \\ Laura Camila Muñoz \\ Colombia \\ Laura Solano Fitzgerald ${ }^{5}$ \\ Colombia}

Para citar este artículo: Ramos, D., Díaz, W., Benítez, S., Muñoz, L. y Solano, L. (2020). Entramados cartográficos de las memorias familiares del semillero Incandescencias. Ciudad Paz-ando, 13(2), 22- 40. doi: https://doi.org/10.14483/2422278X.13988.

Fecha de recepción: 4 de mayo de 2020

Fecha de aprobación: 20 de septiembre de 2020

\footnotetext{
1 Magíster en Estudios Sociales, Universidad Pedagógica Nacional; Maestrante en Artes Plásticas y Visuales, Universidad Nacional de Colombia; Licenciado en Artes Visuales, Universidad Pedagógica Nacional. Coordinador de la Licenciatura en Artes Visuales, Universidad Pedagógica Nacional. Correo: deramosd@pedagogica.edu.co / david.ramos.3@gmail.com ORCID: https://orcid.org/0000-0002-3916-3400

2 Magíster en Estudios Sociales, Universidad Pedagógica Nacional; Licenciada en Artes Visuales, Universidad Pedagógica Nacional. Correo: fba_wjdiazo932@pedagogica.edu.co / wjdo.111q@gmail.com ORCID: https://orcid.org/0000-0003-3415-1141

3 Licenciada en Artes Visuales, Universidad Pedagógica Nacional. Correo: dav_sbenitezp950@pedagogica.edu.co / shasbp4@gmail.com ORCID: https://orcid.org/0000-0003-2533-4974

4 Estudiante de la Licenciatura en Artes Visuales, Universidad Pedagógica Nacional. Correo: lcmunozp@upn.edu.co ORCID: https://orcid org/0000-0001-9661-4995

5 Estudiante de la Licenciatura en Artes Visuales de la Universidad Pedagógica Nacional. Correo: csolanof@upn.edu.co / lacrisofi@hotmail.com ORCID: https://orcid.org/0000-0001-6943-7049
} 


\section{RESUMEN}

En este artículo se pretende dar cuenta del proceso de creación y reflexión alrededor de la "Cartografía de las memorias familiares", realizada durante el año 2018 por el semillero de investigación en Arte y Memoria "Incandescencias: del recuerdo a la Creación”, el cual se encuentra adscrito a la Licenciatura en Artes Visuales de la Universidad Pedagógica Nacional. A lo largo del texto, se narran algunos de los hallazgos encontrados en torno a unos vehículos que articulan las memorias, unos silencios que dialogan con los olvidos y las ausencias, unos recuerdos que muestran un entramado de la memoria y unas herencias que devienen de los procesos de transmisión generacional. Estas reflexiones parten de la necesidad de una aproximación a las memorias familiares desde el lugar de ese otro que dialoga con su pasado, lo cuestiona y resignifica en función del futuro.

Palabras clave: Cartografías de la memoria, herencias, memorias, recuerdos, silencios, vehículos de la memoria.

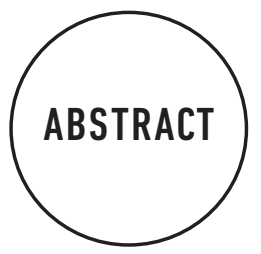

This article aims to give an account of the creation and reflection process around the "family memories cartography", carried out during 2018 by the research hotbed in Art and Memory "Incandescences: from memory to Creation", which is attached to the Bachelor of Visual Arts of the National Pedagogical University. Throughout the text, some of the findings found around some articulate memory vehicles are narrated, some silences conversating with forgetfulness and absences, some memories sowing a memory web and some inheritances that come from the generational transmission processes. These reflections are based on the need for an approach to family memories since the other ones place, who dialogues with his past, questions it and re-signifies it based on the future.

Keywords: Cartographies of memory, inheritances, memories, reminders, silences, vehicles of memory. 


\section{Introducción}

Al usar la palabra incandescencia estamos hablando de una propiedad física que algunos metales o el carbón tienen al exponerse al calor; estos, al llegar a determinada temperatura, emiten una luz de color blanco o rojo. Si comparamos esta idea con el actuar de nuestra memoria, entenderíamos que el acto de recordar haría las veces de "aplicar calor" sobre nuestro pasado y que la luz emergente corresponde a aquellos recuerdos u olvidos que iluminamos para hacerlos aparecer en el presente. De esta analogía surge el nombre del semillero de investigación en Arte y Memoria de la Licenciatura en Artes Visuales de la Universidad Pedagógica Nacional: "Incandescencias: del recuerdo a la creación"6. El grupo nace en el segundo semestre del 2016 a partir de los intereses investigativos y creativos de un grupo de estudiantes y un docente que acompaña el proceso. Incandescencias aparece como un espacio abierto de problematización, producción artística y construcción teórica desde las preguntas y propuestas que nos planteamos de forma individual y colectiva, alrededor de las relaciones entre las memorias personales, familiares, sociales o históricas.

Desde esta apuesta, aquí presentamos algunas reflexiones a propósito de un ejercicio de cartografía de las memorias familiares de los y las integrantes del semillero $^{7}$, a partir de objetos y de las narrativas que estos activan. Esta cartografía, tuvo inicio en el primer semestre del 2018 y fue construida progresivamente en una de las paredes de la Licenciatura en Artes Visuales de la Universidad Pedagógica Nacional (Figura 1).

A continuación, describimos la metodología empleada para este ejercicio investigativo (la cartografía de la memoria, siguiendo la apuesta de Aby Warburg). Posteriormente, narramos los resultados y conclusiones, pues al ir indagando sobre la vida de los allegados de cada integrante del semillero, encontramos que en nuestras memorias familiares los diferentes sucesos -en algunos casos violentos-, al ser compartidos colectivamente, tienen relación con algunos hitos históricos del país como el Bogotazo, la lucha bipartidista, el narcotráfico o el conflicto armado.

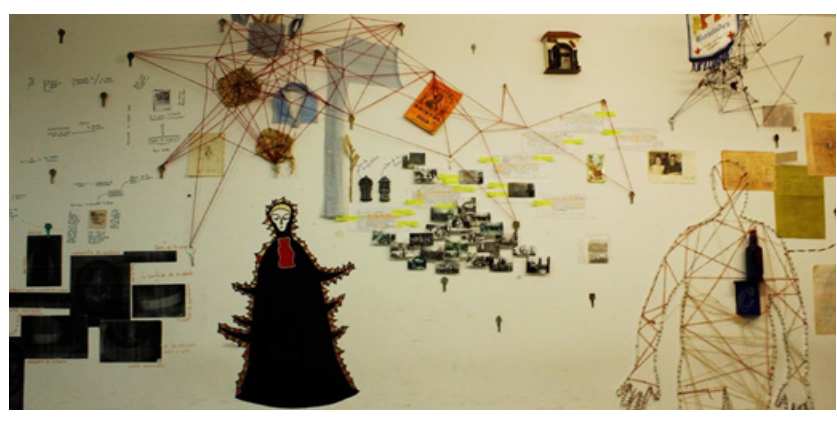

Figura 1: Vista general

"Cartografía de la memoria familiar". Fuente: elaboración propia.

En esta construcción, encontramos varios asuntos que desarrollamos a continuación en torno a unos vehículos que articulan las memorias (específicamente las individuales y colectivas), unos silencios que dialogan con los olvidos y las ausencias sobre el pasado, unos recuerdos que nos muestran un entramado de la memoria y unas herencias que devienen de los procesos de transmisión generacional. Esas reflexiones convergen, a modo de conclusión, en algunos aportes sobre la finalidad de la memoria.

\section{La cartografía como metodología}

Nuestro proceso investigativo se ubica dentro un ejercicio de carácter cualitativo en el que las subjetividades del investigador y de los demás actores implicados son parte del proceso de investigación; por ello, los y las investigadores observan, interactúan, transforman y son transformados por otros sujetos. Esta actividad es relacional y la experiencia investigada puede afectarlos (Vasilachis, 2006). Desde esta perspectiva, nos reconocemos como sujetos-objetos de la evocación y la narración, alrededor del desarrollo de una cartografía de la memoria. Para nosotros, ser sujeto en la investigación significa:

hacernos conscientes de una historicidad que no podemos negar, es reconocer y validar la cultura donde se encuentra nuestra pregunta de investigación, es la posibilidad de compartir y relacionar experiencias/reflexivas con los sujetos-investigados, es colocarnos en situación y con intencionalidad. [...] Ser sujeto en la investigación me obliga a percibir la episteme de manera distinta; como investigador y actor-social me encuentro en constante relación con lo investigado. (Jaramillo, 2006, pp. 112-113)

Esta apuesta de implicación directa con nuestro problema, alrededor de nuestras memorias familiares, la situamos en el uso de la cartografía de la memoria que, en tanto estrategia metodológica, consistió en disponer y categorizar varios objetos seleccionados por los y las integrantes del grupo. El proceso nos permitió establecer relaciones entre objetos y relatos que se activaban sobre
$6 \quad$ El semillero pertenece a la línea de investigación “Di(Sentir): convergencias entre arte, política y educación”, del Grupo Praxis Visual, categorizado en $\mathrm{C}$ por Colciencias.

7 Las reflexiones, los relatos y el ejercicio cartográfico que aquí describimos devienen de los aportes de los integrantes que conforman el grupo: Wendy Díaz Ortiz, Vanessa Alzate Camacho, Hitzamo Beltrán Barrios, Sharon Benítez Pardo, Laura Solano Fitzgerald, Carolany Campos Sandino, Laura Camila Muñoz Pérez, Julián Giraldo Vásquez, Yuly Aros Castro y David Ramos Delgado. 
unas narrativas del pasado, pues nuestra cartografía estuvo cargada de un carácter narrativo de la experiencia, en la que dicha experiencia — siguiendo a Arfuch (2010) cuando retoma los postulados de Ricoeur- está relacionada con la temporalidad para remitir a un pasado que impone su huella como anticipación de lo impredecible.

Desde allí, vimos necesario recoger estos relatos de forma escrita para luego contrastarlos con algunos referentes teóricos que complejizaran nuestros análisis e interpretaciones. Al ir sumando cada vez más objetos que se apropiaron del espacio, relatos y teoría, aparecían nuevas construcciones que se hacían presentes desde los hallazgos categoriales que se construían de manera colectiva.

A medida que fuimos construyendo unas categorías de clasificación ${ }^{8}$, fue necesario generar asociaciones entre elementos. Así fue como, de la mano del Atlas Mnemosyne o Cartografía de la memoria realizado por Aby Warburg, llevamos a cabo el proceso de construcción cartográfico en tanto procedimiento de exploración y presentación de sistemas de relaciones a través del collage y el montaje (Guridi y Tartás, 2013). Entre otras cosas, esta metodología nos permitió evocar o invocar con imágenes (Didi-Huberman, 2010), en nuestro caso, evocar memorias a partir de objetos. De esta manera:

El acto de cartografiar implica la creación de relaciones y la experiencia que establecemos con los espacios; una experiencia que se recrea a partir del ejercicio creativo y se reactiva con los observadores que se relacionan posteriormente con el mapa. Una cartografía es particular, se sitúa precisamente en experiencias subjetivas, nuestra cotidianidad y las maneras particulares de narrar nuestras memorias. (Ramos et al., 2018, p. 45)

Podríamos decir que nuestra cartografía tiene un carácter inacabado, al igual que el atlas, dado que cada vez surgen nuevos relatos que traen consigo los objetos, creando significados en relación con los que, poco a poco, fuimos colocando en la pared. Lo anterior se debe a que "El atlas [...] es por definición necesariamente incompleto una red abierta de relaciones cruzadas, nunca cerrado o definitivo, siempre ampliable a la incorporación de nuevos datos o al descubrimiento de nuevos territorios" (Guridi y Tartás, 2013, p. 229).

Como se verá, la manera en que narramos nuestras memorias familiares, ocurre desde los componentes de nuestra cartografía ${ }^{9}$ los objetos (de ahí el valor del

8 Como categorías iniciales emergieron las siguientes: olvidos, recuerdos, silencios, acto-acción-miedo, herencias y transmisiones, narrativas, bipartidismo, desplazamiento, entre otras que fuimos descartando o reagrupando durante el proceso. Estas fueron afinándose al ser contrastadas con la teoría, de allí la construcción de los resultados y, por tanto, de los aparatados que presentamos en el punto de resultados.

9 Es claro que la idea de Atlas de Warburg excede la forma escritural registro fotográfico que iremos mostrando), los relatos (los cuales dan cuenta de narrativas de los integrantes del semillero) y sus vínculos con algunas apuestas teóricas sobre la memoria.

\section{Resultados: entramados de nuestras memorias}

\section{Los objetos: vehículos de las memorias individuales y colectivas}

Nuestro ejercicio cartográfico parte de la reflexión frente a las memorias familiares, con el fin de ser narradas y organizadas por medio de objetos que tienen lugar en el tiempo y en el espacio. Recordemos que para Halbwachs (2004a) el tiempo y el espacio hacen las veces de marcos sociales de la memoria. Dichos objetos son huellas del pasado y detonantes de recuerdos que activan relatos, de ahí la denominación de vehículos evocativos. Muchos de estos objetos-vehículos contienen una huella oculta de sus propietarios anteriores, son objetos provenientes de un uso personal y privado, cobran sentido desde las narrativas familiares y evidencian el proceso de resignificación desde la evocación.

Este tipo de objetos pueden estar relacionado con los que Baudrillard (1969) presenta como antiguos o marginales, los cuales actúan como testimonio, recuerdo, nostalgia o evasión; por ello:

El objeto antiguo es siempre, en la acepción rigurosa del término, un "retrato de familia". Es en la forma concreta de un objeto donde se realiza la inmemorialización de un ser precedente, proceso que equivale, en el orden de lo imaginario, a una elisión del tiempo. (Baudrillard, 1969, p. 85)

En estos vehículos evocativos identificamos tres grupos, según la función que solían tener antes de pertenecer a la cartografía: objetos de rituales, objetos de registro y objetos utilitarios-cotidianos. Los primeros, cobran sentido desde los significados construidos por la religión católica. Aquí el objeto hace las veces de fetiche, amuleto para la protección o encarnación de una deidad, funcionando como huellas de personas específicas o de instantes precisos de la memoria familiar; por ejemplo, una imagen de la virgen María y una estampa que remiten a la presencia de la abuela de Hitzamo (Figura 2 y Figura 3) o un fragmento de un ramo usado para los "domingos de ramos”, como parte de las prácticas religiosas de la familia de David (Figura 4).

por la cual optamos aquí; sin embargo, somos conscientes de la riqueza visual que la cartografía contiene. Esperamos que el registro fotográfico pueda contribuir en este sentido. 


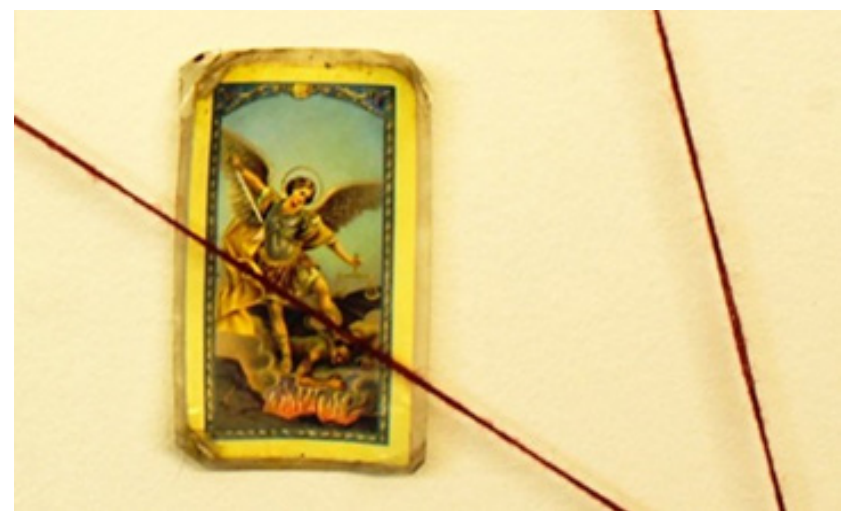

Figura 2: Objeto ritual

Fuente: elaboración propia.

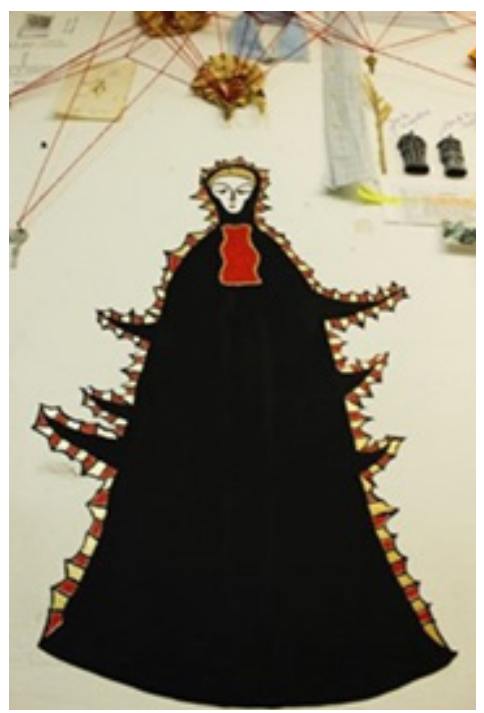

Figura 3:

Objeto ritual: representación de la virgen María. Fuente: elaboración propia.

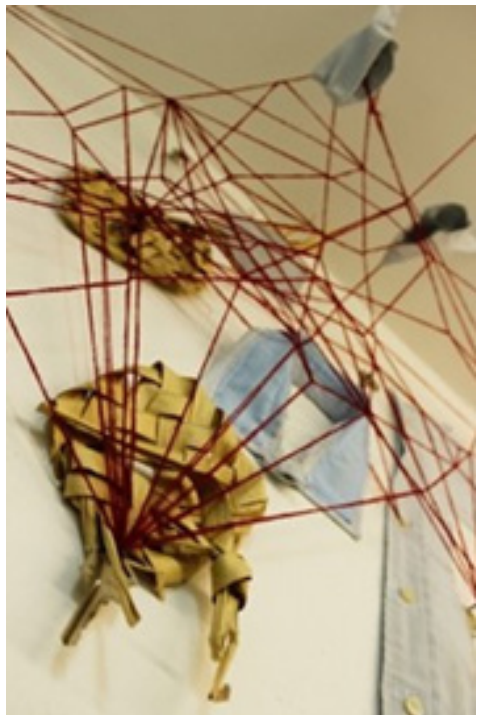

Figura 4: Objeto ritual: ramo. Fuente: elaboración propia
Desde documentos biográficos como cédulas, cartas, partidas de defunción y nacimiento, hasta fotografías, películas o videos, los objetos de registro funcionan como archivo del pasado: piezas arqueológicas que aluden a personajes, fechas, hechos o eventos dignos de ser preservados en el tiempo. Este ejercicio de archivo va más allá de almacenar o coleccionar, se extiende al hecho de consignar para coordinar un corpus dentro de un sistema o una sincronía de elementos seleccionados, articulados y relacionados en una unidad (Guasch, 2010). Por ejemplo, las fotografías de Laura (Figura 5, Figura 6 y Figura 7) son puestas a disposición de la familia desde el álbum, en tanto tienen una carga evocativa y reconstruyen los relatos que en la imagen se concentran; además, las relaciones que propone aportan a la rememoración de otros recuerdos que normalmente no se tienen presentes y son vehículos porque conectan a las nuevas generaciones con sus antepasados.

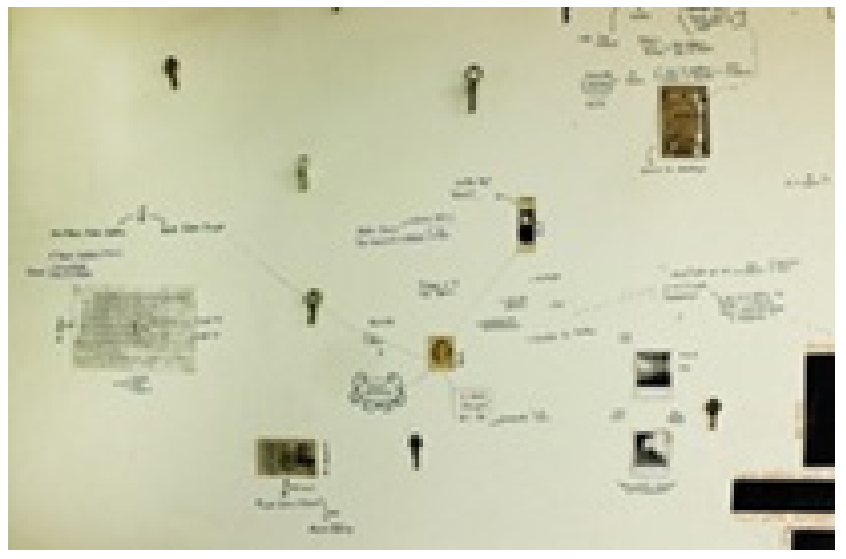

Figura 5: Objetos de registro. Fuente: elaboración propia.

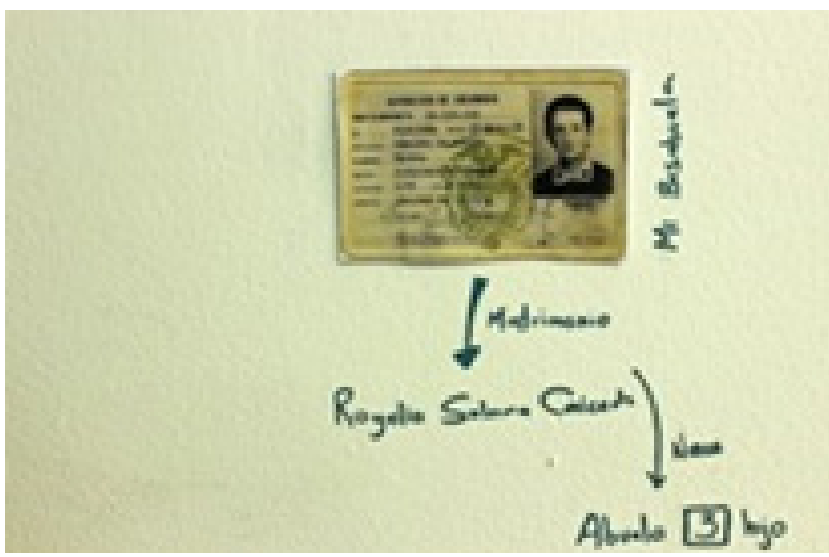

Figura 6: Objeto de registro 1. Fuente: elaboración propia. 


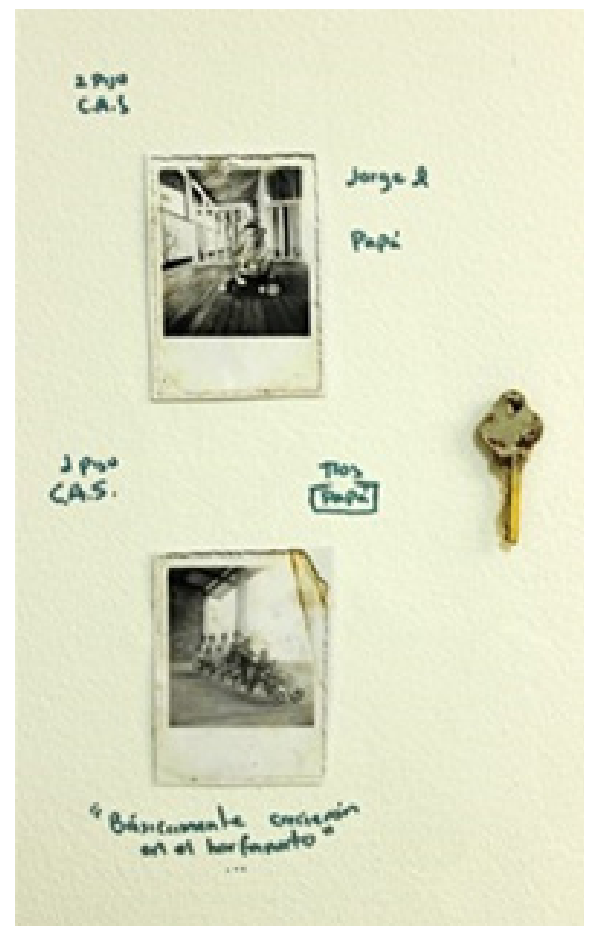

Figura 7: Objeto de registro 2 Fuente: elaboración propia.

En algunos casos, las imágenes logran dar cuenta de una memoria más amplia desde lo que presentan y representan. Siguiendo el relato de Laura desde las fotos que conforman la cartografía, se puede decir que:

El encuentro con las fotografias relata macrohistorias desde la memoria familiar, pues esas imágenes representan una época violenta y una serie de asociaciones con la esencia familiar. Estas imágenes fueron el escondite de recuerdos silenciados por el paso del tiempo, quizá escapando de vacilantes sucesos, o el simple hecho de tener miedo al pasado. Más que portar un apellido, es compartir unas experiencias y entender el porqué de la esencia, solo se debe aprender del pasado y, para descubrir esa historia, las imágenes petrificadas en el tiempo son la huella de un ayer en blanco y negro. (Comunicación personal, Laura, 2018)

El tercer grupo de vehículos evocativos, los objetos utilitarios-cotidianos. Tienen la particularidad de que dentro de nuestra cartografía pierden su finalidad inicial doméstica y utilitaria —estos objetos Baudrillard (1969) los cataloga como funcionales-. Así, pasan a convertirse en objetos con valor simbólico para recordar y evocar. Las llaves que Wendy ubica y que se pueden ver en toda la cartografía (Figura 8) hacen parte de este grupo de objetos porque su objetivo inicial — su producción era el empleo de su padre- ahora es modificado: las llaves son retomadas como detonante de la memoria para aludir a la manera como su padre tuvo que desplazarse como consecuencia de una amenaza.

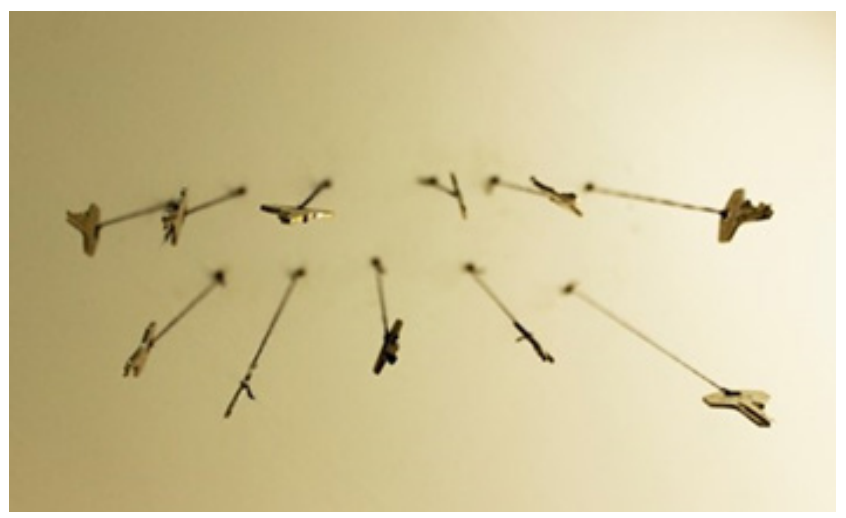

Figura 8: Objeto utilitario-cotidiano: llaves. Fuente: elaboración propia.

Así, lo relata Wendy:

Las llaves, ¿cómo llegaron ahí? La respuesta es muy simple, de mi padre. Pero ¿cómo llegaron a él? Esto no es tan simple. Verán, en su época juvenil la pelea parecía ser una actividad de ocio. Al menos para él y su mejor amigo Pedro Delgado, quienes en las noches llegaban a las tabernas a empezar peleas o a terminarlas. Todo fue así de repetitivo hasta que un día alguien pasó gritando " $i Q u e$ viva el M-19!" cerca de un sitio en el que ellos se encontraban. No se sabe quién les dijo a los policías que habían sido mi papá y Pedro, el caso es que los encerraron, como de costumbre. Cuando los dejaron salir, sin querer el papá de Pedro tuvo una conversación con un policía que le decía que a esos muchachos los iban a matar. Por esta razón mi papá salió del pueblo dejando la casa de su madre. Por eso y por un telegrama de Gilberto García que decía: "Adolfo sí quiere trabajar lo espero el lunes en Bogotá". Así fue como las llaves llegaron a él, en Bogotá aprendió a hacerlas con Gilberto García. (Comunicación personal, Wendy, 2018)

Podemos decir que cada uno de los objetos que hemos descrito hasta aquí y la cartografía que construimos funcionan como vehículos de memoria porque agrupan, organizan y evidencian las memorias individuales, haciéndolas colectivas y generando un entramado narrativo, pues:

La memoria $[\ldots]$ se produce en tanto hay sujetos que comparten una cultura, en tanto hay agentes sociales que intentan "materializar" estos sentidos del pasado en diversos productos culturales que son concebidos como, o que se convierten en, vehículos de la memoria, tales como libros, museos, monumentos, películas o libros de historia. (Van Alphen citado por Jelin, 2002, p. 37) 
Desde esta perspectiva, encontramos dos momentos que constituyen al objeto y a la cartografía como vehículos de la memoria. Por un lado, se narra la memoria individual o familiar, condensando el recuerdo en la materialidad de un objeto y en su carácter de vehículo evocativo, para ubicarlo dentro de la cartografía. Luego, la construcción cartográfica hace visible la emergencia de una memoria más amplía, pues tanto quienes realizamos la cartografía como quienes la observan, encuentran relaciones que los transportan a sus propios recuerdos, en función de hechos sociales e históricos más amplios o experiencias y prácticas compartidas. Siguiendo a Halbwachs (2004b):

Cabe decir que cada memoria individual es un punto de vista sobre la memoria colectiva, que este punto de vista cambia según el lugar que ocupa en ella, y que este mismo punto de vista cambia según el lugar que ocupo en ella y que este mismo lugar cambia según las relaciones que mantengo con otros entornos. [...] Sin embargo, cuando tratamos de explicar esta diversidad, volvemos siempre a una combinación de influencias que son todas de tipo social. (p. 50)

A partir de esa rememoración común, podríamos afirmar que los recuerdos, a pesar de ser comunicados y experienciados por cada sujeto, siempre están en relación con estructuras más amplias como el tiempo y el espacio (Halbwachs, 2004b), vehiculándose por procesos de comunicación y del lenguaje en tanto construcciones sociales que legitiman lo que se recuerda o no (Vázquez, 2001).

Es posible edificar la tensión entre memoria individual y colectiva en el relato de Carolany, quien narra las experiencias de vida de su mamá y su familia, materializadas en la cartografía a través de la ceniza (Figura 9):

Vivíamos en el Cesar. La guerrilla pedía un pago, y cuando el patrón no estaba y no dejaba el dinero, eran los trabajadores los que salían perjudicados, ya que violaban a las mujeres, se llevaban a los niños y mataban a los hombres; además, se llevaban los productos y el ganado de la finca. Por eso nos cambiamos de lugar, para una parcela que compró mi papá. En ese lugar yo hacía quesitos y los vendía hasta que mi papá se enteró que eran usados para esconder y transportar droga. Después decidimos mudarnos a Guaduas, pero fue necesario retrasar el viaje a causa de la toma del Palacio de Justicia y cuando logramos llegar, todo estaba cubierto por las cenizas del volcán Nevado del Ruiz. (Comunicación personal, Carolany, 2018)

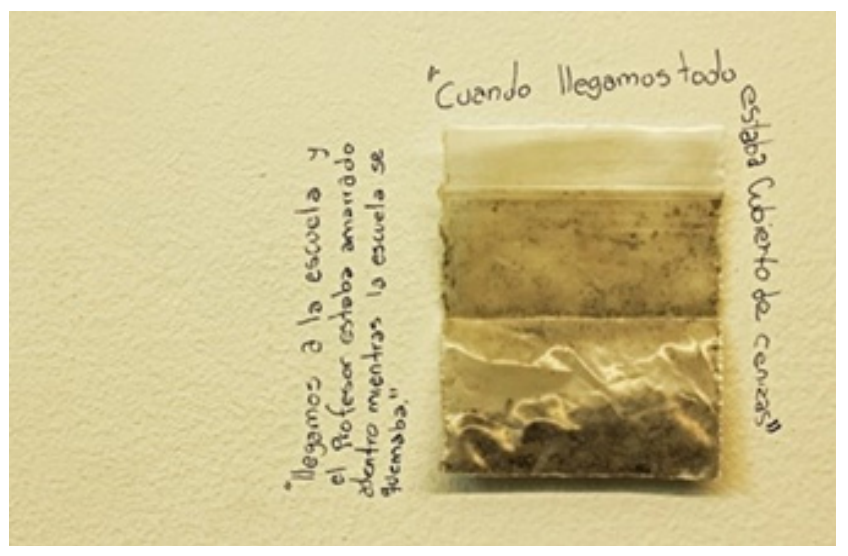

Figura 9: Cenizas.

Fuente: elaboración propia.

El relato anterior nos deja entender la manera como los hechos ocurridos de forma trasversal en la historia de nuestro país se entrecruzan con los relatos individuales y de colectivos pequeños. Hechos comunes en Colombia como la guerrilla, el desplazamiento forzado, el narcotráfico, los desastres naturales y las coyunturas políticas, afectan las experiencias individuales, evidenciando las fibras internas dentro del gran entramado histórico y situando a quienes escuchan el relato en contextos especíicos.

En el siguiente relato, David refuerza esta idea de construcción colectiva de la memoria a partir de su memoria familiar, pues parte de un hito social para organizar su búsqueda y recolección de sucesos dentro de su familia. Construye su narrativa a partir de una fecha importante que sigue vigente en el imaginario colectivo del país, vinculándose con fechas relacionadas con sus antepasados, las cuales encontró en varios documentos (Figura 10 y Figura 11).

Cuando encontré las actas de bautizo y algunas actas de defunción de mis antepasados, en este caso los portadores de mi apellido paterno, tuve la necesidad de contrastarlas con un acontecimiento que mi abuelo vivió: el bogotazo. Tomando como referencia esta fecha —el 9 de abril de 1948 - puedo decir: que Juan Crisóstomo Ramos, el papá de mi tatarabuelo, murió el siete de abril de 1940, ocho años antes del bogotazo; que mi tatarabuelo, Diego Ramos, nació el once de noviembre de 1865, ochenta y tres antes del bogotazo; que Secundino Ramos, mi bisabuelo, nació el 7 de diciembre de 1892 y murió el 18 de agosto de 1973, respectivamente corresponde a cincuenta y seis años antes y veinticinco años después del bogotazo; que mi abuelo Jorge Ramos fue bautizado el 25 de mayo de 1930, dieciocho años antes de haber presenciado el bogotazo; que Jorge Ramos, mi papá, fue bautizado el 24 de octubre de 1954, seis años después del bogotazo; y que mi bautizo fue el 18 de diciembre de 1988, cuarenta años después del bogotazo. (Comunicación personal, David, 2018) 


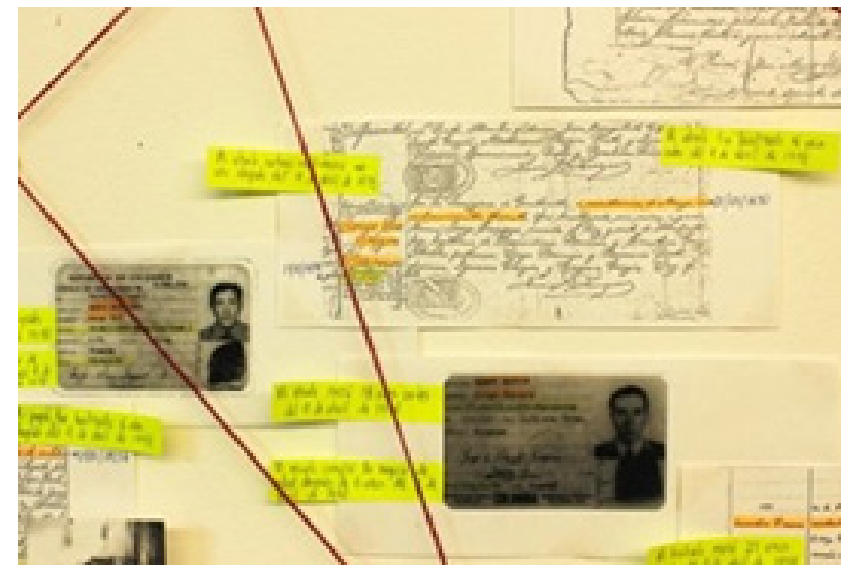

Figura 10: Reproducción de cédulas, actas y partidas 1 .

Fuente: elaboración propia.

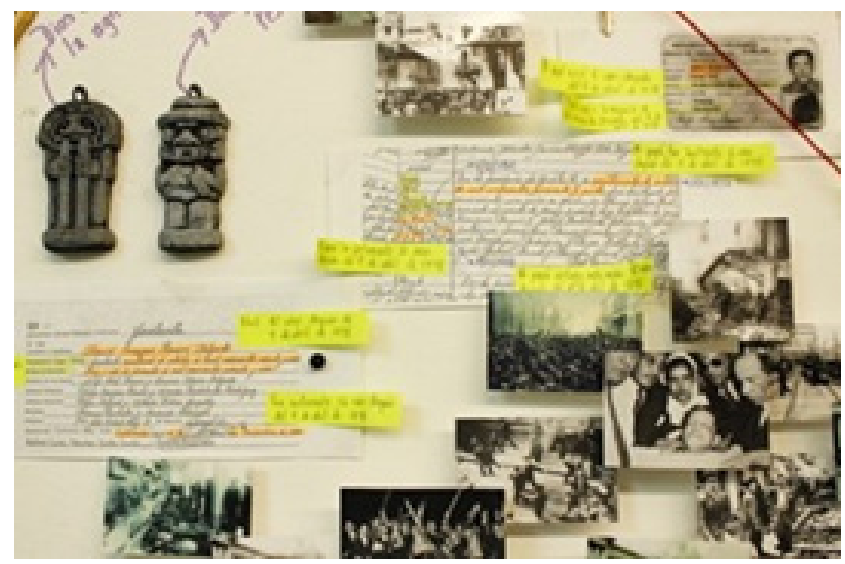

Figura 11: Reproducción de cédulas, actas y partidas 2 .

Fuente: elaboración propia.

Siguiendo la narrativa de David en relación con estos cruces entre memorias individuales y colectivas a la luz del Bogotazo, nos cuenta cómo su abuelo presenció este hecho que ocurre en un contexto más amplio fuera de la familia, mostrando las influencias de acontecimientos sociales en las experiencias de vida de los sujetos. Lo anterior a partir de las fotografías que encontró de un fotógrafo de la época documentando el evento (Figura 12), cosa que también podemos vincular con la importancia del Bogotazo materializado en imagen, David nos cuenta:

En 1948 mi abuelo, Jorge, trabajaba en una panadería del centro de Bogotá, creo que ahí conoció a mi abuela; un tiempo después, volvió al pueblo para casarse con ella. El caso es que, según me contaba, el 9 de abril presenció el asesinato de Gaitán, no lo vio directamente, pero recordaba cómo estaban los muertos tirados en las calles y cómo el humo salía de los edificios. Cada vez que mi abuelo hablaba del tema decía algo así: ¡Juelita, era un arrume de muertos tirados, ahí, en la calle! Las imágenes que llegan a mi cabeza son como las fotografías del bogotazo de Manuel H.: el tranvía incendiándose, la multitud armada con machete, las casas en ruinas... Por supuesto, las fotos —así como las escenas en mi mente- son grises, borrosas y frágiles. (Comunicación personal, David, 2018)

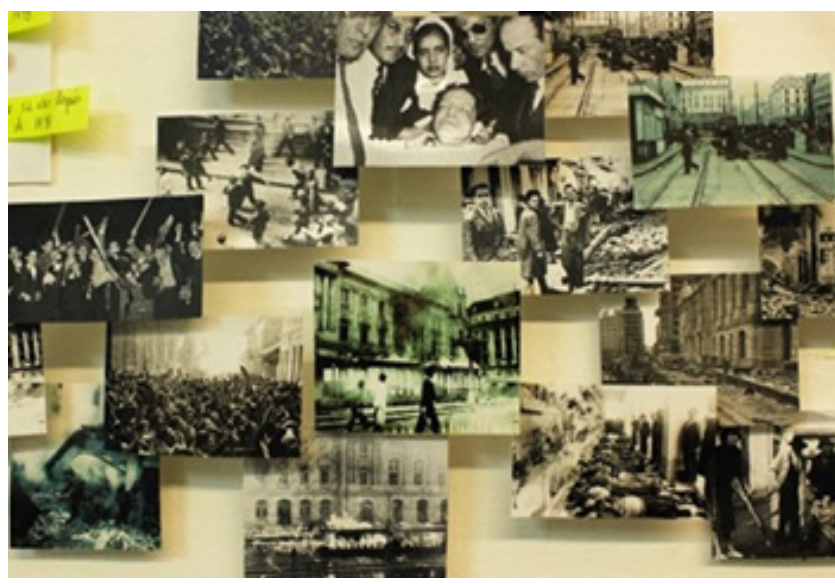

Figura 12: Fotografías del Bogotazo Fuente: elaboración propia.

Con lo dicho hasta ahora, cabe decir que, dentro de esta cartografía, las memorias en sus formas individuales y colectivas aparecen vehiculadas mediante objetos, los cuales solo cobran sentido cuando conocemos el pasado que contienen a partir de las narrativas evocadas, pues "la memoria es narrativa en un doble sentido, como relato de progresión de acontecimientos en el hilo del tiempo, y como conformación de una trama (con actores, escenarios y acciones)" (Mendoza, 2005, p. 16). Al respecto, Arfuch (2010) nos advierte que el tiempo se torna humano cuando es articulado de un modo narrativo; según ella, el relato no solo remite a un acontecimiento secuencial, sino a una forma de estructuración de la vida y la identidad.

La noción de vehículos evocativos y las narrativas en torno a ellos nos permitieron entender que varios de estos objetos pertenecen a una memoria de una colectividad más amplía como la familiar y la histórica. Es así como la recopilación del pasado converge en el reconocimiento de unos recuerdos, unos silencios y unas herencias particulares, las cuales narraremos en los apartados que siguen y que inciden en unos hechos marcados socialmente por contextos de violencia en Colombia -en la mayoría de los casos- apelando a las memorias individuales que atraviesan sucesos de una índole más vasta. 


\section{Los silencios de nuestras memorias: entre los olvidos y las ausencias}

Candau (2006) nos hace la siguiente advertencia:

sería un error definir siempre al olvido por la falta. Los olvidos son vacíos llenos de algo, como señalaba R. Bastide. [...] La memoria olvidadiza no es siempre un campo de ruinas, también puede ser un lugar de trabajo. Por consiguiente, no hay que percibir obligatoriamente el olvido como una privación, un "déficit”. (p. 81)

Al lado del recuerdo se encuentran también pequeños lugares oscuros, borrados o suprimidos que hacen parte del relato y la memoria. En la misma medida en que se nos niega una información, se nos brinda otra. Hay cosas que no se dicen porque son irrelevantes y otras que se callan, precisamente, por esa trascendencia que las carga. Esto es lo que Jelin (2002) refiere cuando asegura que la memoria es selectiva. Hay aspectos del pasado que los actores deciden callar.

Así pues, el relato de Sharon cuenta un hecho que marcó la vida de su abuela y que representa un silencio en la memoria:

La historia comienza con un silencio. El silencio de mi abuela, una mujer campesina que sin saber leer ni escribir, pero con mucho conocimiento de la vida, se encuentra de repente con un hombre, su primer amor, y también el demonio que marcó su silencio. Este hombre la saca de su casa, una casa redonda con techo de paja y camas de guadua ubicada en la vereda el Cucharo de Chipatá, Santander del Sur, donde el fogón estaba hecho de tres piedras, se ubicaba en la mitad de la casa y la olla colgaba de un gancho que venía del techo. Con él, mi abuela tiene dos hijas a las que él decide negar el apellido, y marca el principio de un silencio extendido en el tiempo que la lleva a dejarlo por la violencia de género, tan llena de rabia en su corazón que no vuelve a conocer hombre alguno. Así, ella llega a Bogotá con una niña de tres años y otra de ocho días de nacida, con un costal de ropa y nada más. Aparentemente el primer objeto de esta historia es la nada, una nada que representa el silencio profundo que guardó mi abuela a lo largo de su vida, y a pesar de ser una mujer supremamente religiosa, cuando alguien imprudentemente le preguntaba por el padre de sus hijas, la única palabra que salía de su boca era "el diablo". (Comunicación personal, Sharon, 2018)

En este relato, la imagen del diablo metaforiza el silencio. Llama la atención que el relato de Sharon no cuenta con un objeto material dentro de la cartografía, lo que refuerza esta idea. La protagonista, al ser violentada, toma la decisión de irse con sus hijas y dejar a este hombre del que no revela su identidad. En su lugar, lo relaciona con el diablo, una figura que, de algún modo, "encarna el mal".
Podemos decir que el silencio entra en relación con las ausencias y los olvidos, la diferencia está en que el silencio parte de la idea de lo no dicho, y las ausencias y olvidos parten de la idea de falta, algo que marcó el recuerdo pero que se perdió. Según Pollak y Heinich citados por Jelin (2002), los silencios presentes en las narrativas personales son fundamentales porque son opciones que funcionan como modo de gestión de la identidad. Por ello, "El olvido es una censura pero también puede ser una carta de triunfo que le permite a la persona o al grupo construir o restaurar una imagen de ellos mismos globalmente satisfactoria" (Candau, 2006, pp. 81-82). Para ejemplificar esto, el relato de Vanessa demuestra un silencio caracterizado por callar un acontecimiento que resulta penoso para la familia. En este afirma:

El tono en que mi abuela narra su historia evidencia el desagrado y la vergüenza que le produce. Sé que omite muchos hechos por pena a que lo sepan. Sé, además, que su familia (mis tías-abuelas y su descendencia) nos miran con lástima, porque ellos han intentado cubrir la historia del desplazamiento con dinero y bienes. (Comunicación personal, Vanessa, 2018)

En el relato anterior identificamos un silencio en la memoria familiar. Para la abuela de Vanessa fue un proceso de omisión porque creó un obstáculo en el testimonio y también un hueco, un vacío en su memoria. Según Jelin (2002), el relato no tiene el mismo sentido para quien lo cuenta como para quien lo escucha; asimismo, se cambia la historia evitando datos que generan molestia a quien lo narra. Por otro lado, quien lo escucha nota que hay faltantes y lo interpreta cambiando el sentido del relato. Es de esta manera como, en la memoria de la familia de Vanessa ella es quien identifica lo ausente, ya que se fue creando el silencio durante generaciones.

Por lo tanto, los testimonios también pueden dar cuenta de la dificultad que hay entre lo que se puede decir o no. El relato de Wendy, que parte de un suvenir (Figura 13), se caracteriza por traer diferentes incógnitas del pasado de su padre que ella misma silencia, creando también rupturas en el legado de la memoria familiar.

La casa para las llaves la compré en Suratá, Santander, el pueblo del cual mi papá salió amenazado y en el que aún vive mi nona (así les dicen allá a las abuelas). Antes de que mi papá saliera de allí, pasaron muchas cosas que prefiero no saber. Pero que, sin embargo, llegan a mí por un interlocutor diferente a él, siendo historias incompletas que lo identifican a él como victimario. Esbozando de a pocos la razón por la que, durante mucho tiempo, perdió contacto con mi nona luego de dejar su casa. (Comunicación personal, Wendy, 2018) 


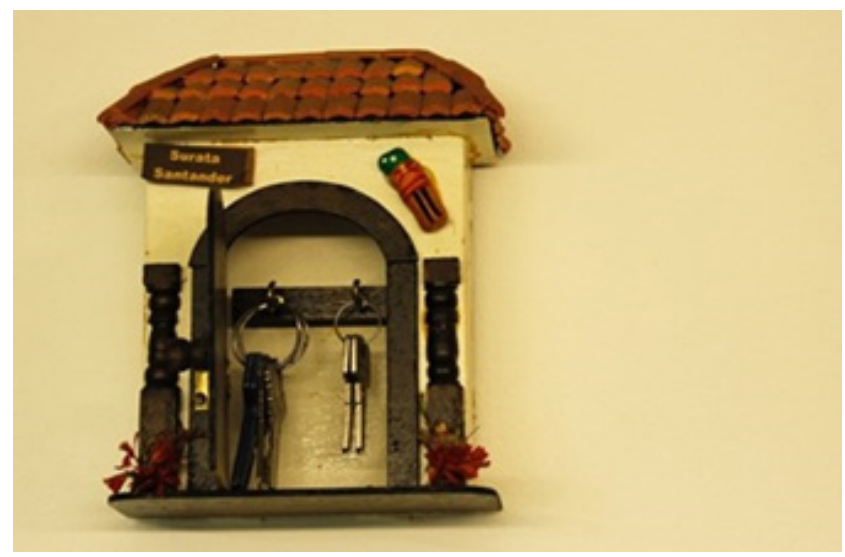

Figura 13: Suvenir, casa para las llaves. Fuente: elaboración propia.

Otro relato que reflexiona sobre los silencios que se narran de manera poética para que no duelan al ser contados es el de Julián. Nos muestra varios objetos presentados como archivadores de memoria: un cajón, como un relicario, que se despliega, se encierra, se guarda y se retira, a veces se desborda y acoge diversos sucesos que en cualquier momento quedan en secreto, olvidados (Figura 14-Figura 17). Julián lo narra de la siguiente manera:

Si tienen ojos que no me vean, si tienen manos que no me toquen, si tienen pies que no me alcancen (oración del santo juez). Para todos, el romper los silencios, abarrotar de memorias como el pasado nos cuenta en el ahora, es como abrir los cajones de un mueble. Hay muchos cajones: unos sellados, otros medioabiertos, otros que se desbordan de cosas y otros vacíos; cajones con objetos: relicarios para recordar. El escarbar, desentrañar actos o sucesos que como con un papel mantequilla se ve a través de él, no se puede tocar, porque lastima. Aquel hilo que se enreda, pero que a la vez conecta, es la llave para encontrar los temores, sonrisas y llantos que se cuentan para recordar algo que muta, y que se acomoda para lo que queremos contar. (Comunicación personal, Julián, 2018)

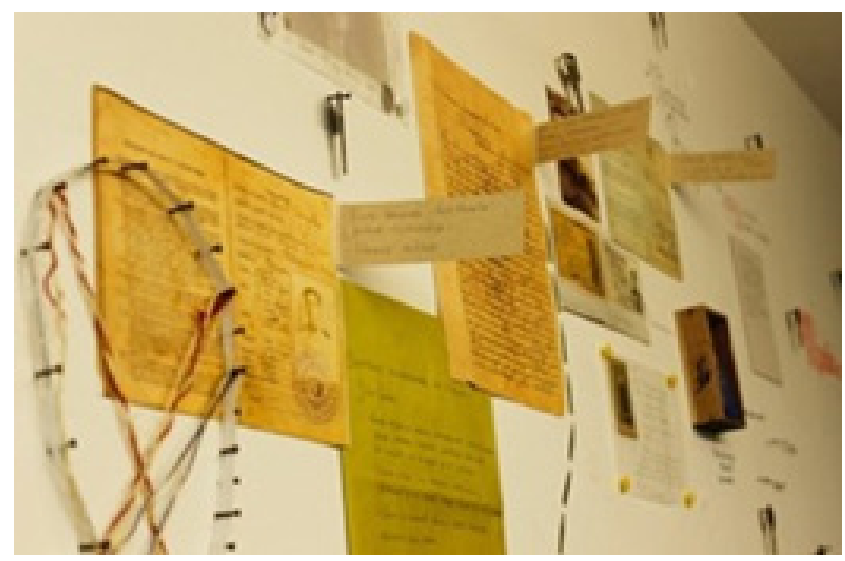

Figura 14: Objeto-huella del silencio 1. Fuente: elaboración propia.

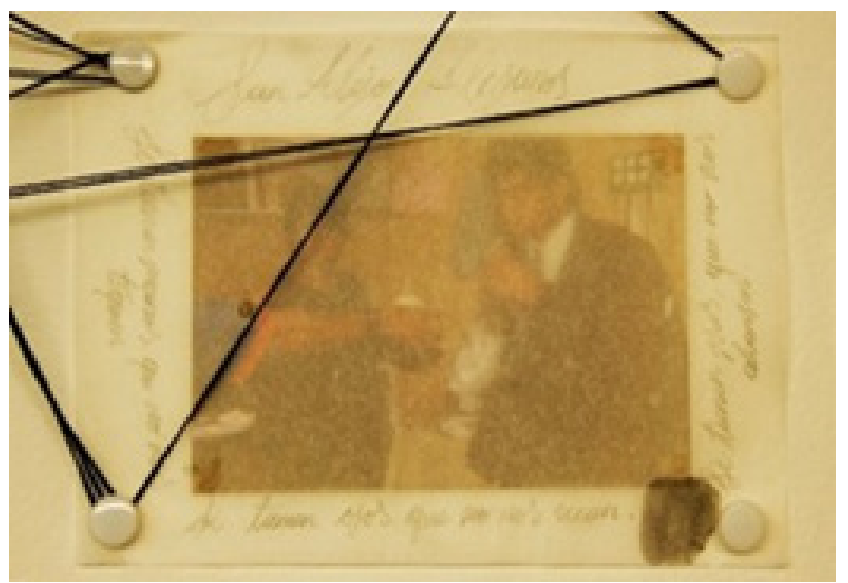

Figura 15: Objeto-huella del silencio 2 . Fuente: elaboración propia.

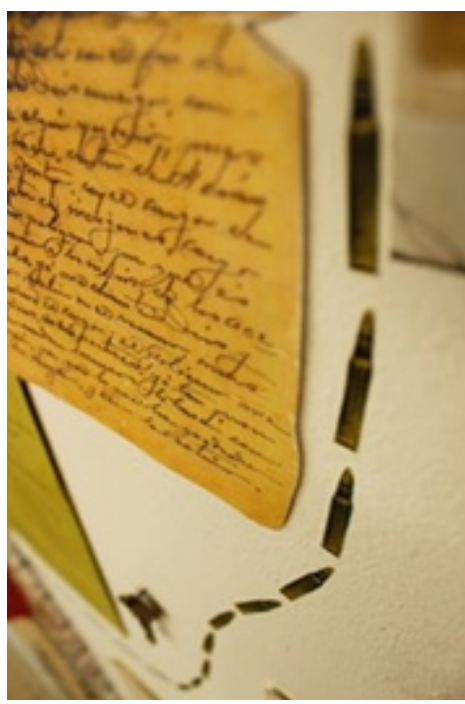

Figura 16: Objeto-huella del silencio 4 Fuente: elaboración propia

\section{Génesis y entramados de nuestros recuerdos}

Para Guasch (2005), la mnéme o anámesis hace referencia a la propia memoria, a la memoria viva o espontánea, mientras que la hypomnema se relaciona con la acción misma de recordar. Siguiendo a la autora, estos dos principios se refieren a la fascinación por almacenar memoria: cosas salvadas a modo de recuerdos. Por esto, partimos de entender el recuerdo como esa acción de rememorar un hecho que deseamos permanezca vivo y salvaguardado. Contar ese suceso facilita que se quede, pero hay relatos que no se cuentan, y a pesar de eso no se olvidan, pues han marcado de tal manera la vida que prevalecen sobre el olvido al verse atraídos a la luz con la ayuda de vehículos que los llaman a aparecer de nuevo. 
Como ya se dijo, la memoria, pese a ser personal y única, se entreteje con otras memorias, que juntas se complementan, esto mismo acurre con los recuerdos. Cuando los recuerdos individuales se entrelazan y se amplían, se convierten en un vínculo entre las personas para construir una memoria social, a partir de diálogos alrededor de hechos comunes. Por ello:

Cada persona tiene "sus propios recuerdos" que no pueden ser transmitidos a otros. Es esta singularidad de los recuerdos, y la posibilidad de activar el pasado en el presente [...] lo que define la identidad personal y la continuidad del sí mismo en el tiempo. Estos procesos no ocurren en individuos aislados sino insertos en redes de relaciones sociales, en grupos, instituciones y culturas. De inmediato y sin solución de continuidad, el pasaje de lo individual a lo social e interactivo se impone. (Jelin, 2002, p. 19)

Hay que aclarar que cuando recordamos tejemos nuestras experiencias con otros tiempos, otros espacios, otras personas, sensaciones y emociones que, dependiendo de dónde y cuándo estemos, varían. Estas variaciones del recuerdo dependen de asuntos como nuestra edad, creencias, de quien narra el pasado, hasta de la afectividad frente a los personajes y situaciones recordadas. Encontramos que los recuerdos ponen en tensión unas formas particulares de reconstruir el pasado, en función de lo que queremos narrar para no olvidar. "Existen acuerdos narrativos que 'modelan las experiencias', para que se indique cómo hay que vivenciarlas, para darle un sentido al mundo. Estas formas de discurso son un modo de organizar también la experiencia pasada" (Mendoza, 2005, p. 13). Y fue a partir de esta organización que identificamos en la cartografía una serie de hechos vinculados con contextos de violencia. ¿Quién recuerda y qué personas vivenciaron esas exxperiencias narradas?, ¿qué actores marcaron ese pasado que algunas veces evidencia unas vivencias dolorosas?, ¿en dónde y en qué circunstancias sociales, históricas, políticas... se produjeron?, o ¿qué hechos marcaron aquello que se narra?

Estos interrogantes no son más que elementos que quisimos señalar en algunos recuerdos que pudimos crear y recrear en torno a unas huellas, unas evidencias materiales de nuestras memorias familiares: los objetos. Así fue como reconocimos unas víctimas que "protagonizan" y a veces narran ese pasado; identificamos a unos actores - en la mayoría figuras masculinas- asociados con actos violentos. Podemos hablar de unas situaciones que dan cuenta de un contexto social más amplio, vinculadas con un pasado doloroso y relacionamos unas acciones equivalentes a hechos violentos vivenciados por unos sujetos.

Como se ve a continuación en los relatos, el hilo conductor es el miedo: a perder la vida propia o del ser querido, a perder la tierra, a perder la fe... Un miedo que, como refiere Bauman (2007), es inherente a todas las criaturas vivas como respuesta a una amenaza que pone en peligro la vida, pero que, en el caso de los seres humanos, tiene un sentimiento adicional construido social y culturalmente: un miedo derivado o secundario que orienta las conductas. En otras palabras:

El "miedo derivativo" es un fotograma fijo de la mente que podemos describir [...] como el sentimiento de ser susceptible al peligro: una sensación de inseguridad (el mundo está lleno de peligros que pueden caer sobre nosotros y materializarse en cualquier momento sin apenas mediar aviso) y de vulnerabilidad (si el peligro nos agrede, habrá pocas o nulas posibilidades de escapar a él o de hacerle frente con una defensa eficaz; la suposición de nuestra vulnerabilidad frente a los peligros no depende tanto del volumen o la naturaleza de las amenazas reales corno de la ausencia de confianza en las defensas disponibles). (Bauman, 2007, pp. 11-12)

Visto de este modo, el miedo aparece como eje transversal en nuestra cartografía. Por ejemplo, Laura narra la manera como su abuelo se enfrentó al cura de la iglesia en torno a una disputa por la fe católica, y que trajo como consecuencia una acción violenta. Así lo relata a partir de algunas fotografías y textos que coloca en dentro de la cartografía del semillero (Figura 18 y Figura 19):

El cura del pueblo llega donde el odontólogo y le dice: - Tenemos que ir el domingo a una reunión con unos evangélicos que llegaron y se situaron al otro lado del río y están captando a los feligreses de la iglesia católica, y no debemos permitir que nos vengan a corromper-. Como a las 5 p. m., el odontólogo escucha una algarabía de la gente que venía de regreso, golpeando fuerte a la puerta, llamando al odontólogo. Abren la puerta y era el cura diciendo que cuando iban llegando al río, bajaron hombres armados y pensaron que eran vándalos de la época y con la policía mataron a las personas sin identificarse, pero resultó ser que eran policías del otro pueblo. Entonces, ante ese cuento del cura, el odontólogo le dijo — ¡Grave!, el responsable de todo es usted-. Y el sacerdote salió furioso, insultando, y reunió al pueblo y prendieron fuego a la casa mientras gritaban: -En Colombia no queremos protestantes que nos quieran corromper-. Un familiar que estaba cerca se metió por la parte de atrás de la casa y logró sacar a los menores, los metieron en un camión y se los llevaron de allí. (Comunicación personal, Laura, 2018) 


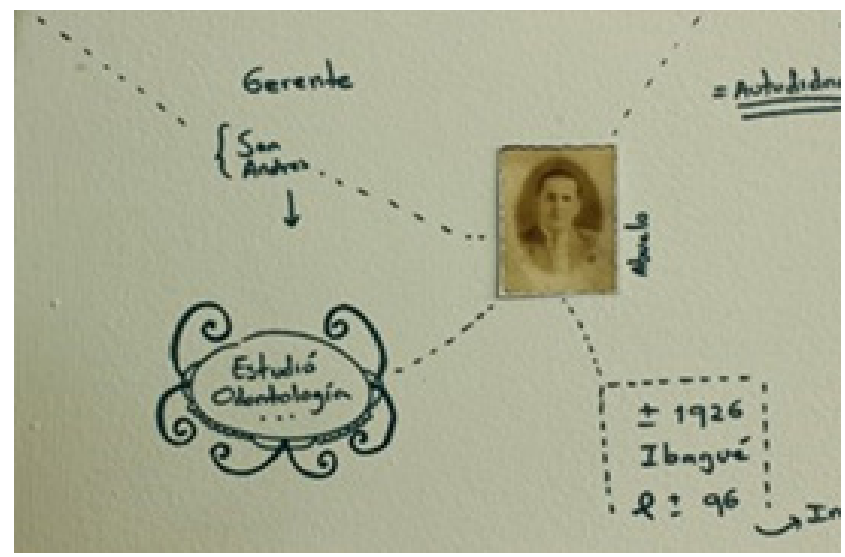

Figura 17:

Activadores del recuerdo: fotografías y relatos 1. Fuente: elaboración propia.

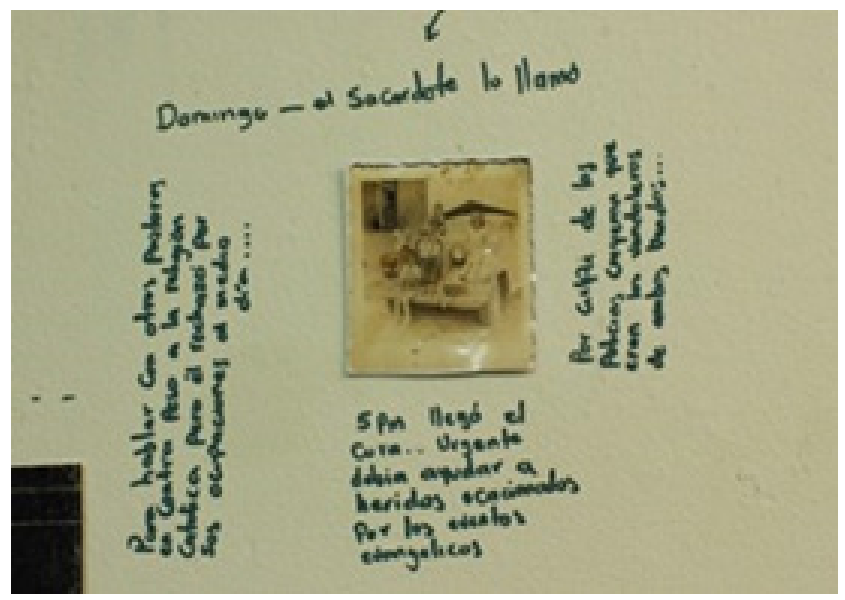

Figura 18:

Activadores del recuerdo: fotografías y relatos 2 . Fuente: elaboración propia.

Otro de los miedos que identificamos en los relatos tiene que ver con el desplazamiento forzado como una de las acciones que deviene del periodo de la Violencia bipartidista en el país, durante las décadas posteriores al Bogotazo. Como ocurre en el relato de Vanessa (Figura 20):

Los objetos que detonaron mi búsqueda fueron la cruz de mi abuela y la lista de mercado que se encontraba debajo de ella, hecha por mi papá hace algún tiempo. Estaban ubicados (de esa manera) en la repisa de la cocina. Al preguntarle a mi abuela sobre la cruz, me dice que junto con una navaja que tenía guardada, son los únicos recuerdos (físicos) que tiene de su papá y su abuelo, antes de ser sacados a la fuerza de su finca por la Violencia -época de la violencia bipartidista - como ella la denomina. (Comunicación personal, Vanessa, 2018)

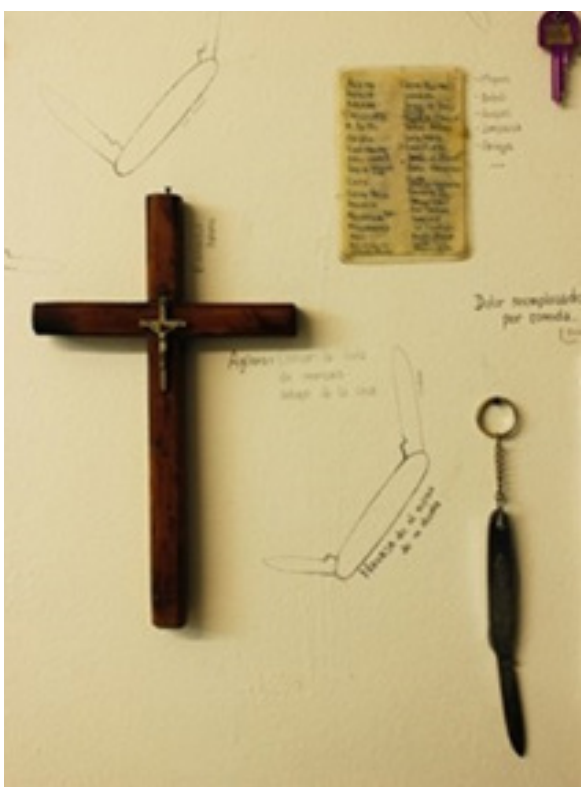

Figura 19:

Activadores del recuerdo: cruz y lista del mercado. Fuente: elaboración propia.

En relación con el relato anterior de Vanessa, el aporte de Yuly a la cartografía narra la manera como su abuela y su familia, vivenciaron el desplazamiento forzado reiteradamente, ello como consecuencia del bipartidismo de los años cincuenta y, recientemente, el conflicto armado de los años noventa y la primera década del 2000. Yuly materializa los recuerdos desde objetos que ella misma fábrica o interviene (Figura 21-Figura 24), creando metáforas sobre la memoria de su abuela que resume en el siguiente relato:

La violencia para mi abuelita ha estado presente, afectándola directa e indirectamente en diferentes momentos de su vida. Empezando por la época en que, siendo una niña, dedicaba su tiempo a jugar con botellas; en 1958 sobrevive a la guerra bipartidista donde mueren su padre, su abuelo, su tío y su abuelita; - Dejaron a mi abuelita colgada entre los alambres-, dice ella. Inició así una vida de desplazamiento y testificación de la guerra. A partir de las fotos con solo las siluetas de personas que hoy ya no están, estas imágenes corresponden a la narración de ella: —Llegamos con mi esposo a la finca El silencio en 1995. A la finca a veces llegaba el ejército y en otras ocasiones llegaba la guerrilla, ambos acampaban por ahí cerca a la casa, claro que no al mismo tiempo, eso siempre dio mucho susto, que llegaran a encontrarse preciso ahí en la finca. Tocaba pagarle vacuna a la guerrilla y a los paramilitares, a esos nunca los vimos, pero enviaban mensajero. En las fotos, el chino que salía en el cultivo de amapola era miliciano, a él lo cogieron y se lo llevaron para la cárcel, no volví a saber nada sobre él一. Finalmente mi abuela tuvo que volver a encontrarse en situación de desplaza- 
miento. Dice ella: - Tuvimos que irnos porque a la casa de un vecino que tenía tienda, llego el ejército mientras estaba la guerrilla allá y hubo una plomacera muy terrible, resulta que el hijo del vecino era miliciano y se lo llevaron para la cárcel, allá, a esa casa llegaron chismes de que nosotros habíamos mandado el ejército, eso fue en el 2007. (Comunicación personal, Yuly, 2018)

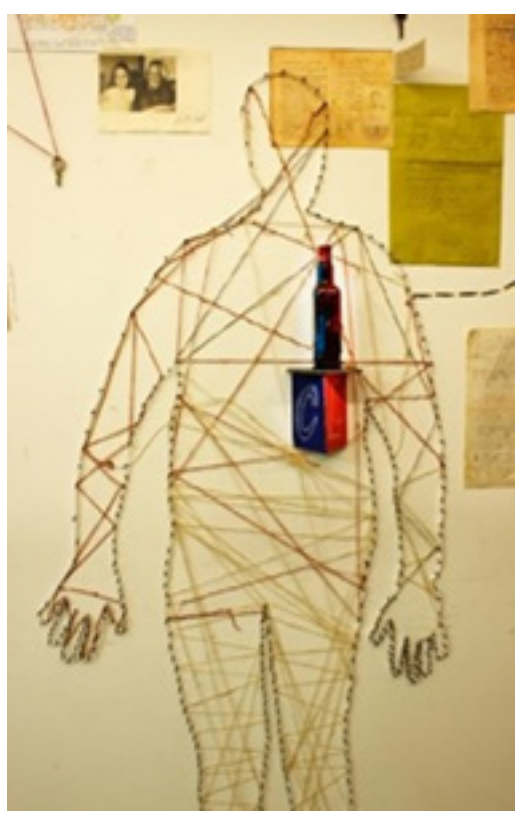

Figura 20:

Activadores del recuerdo: reproducción de botella 1 . Fuente: elaboración propia.

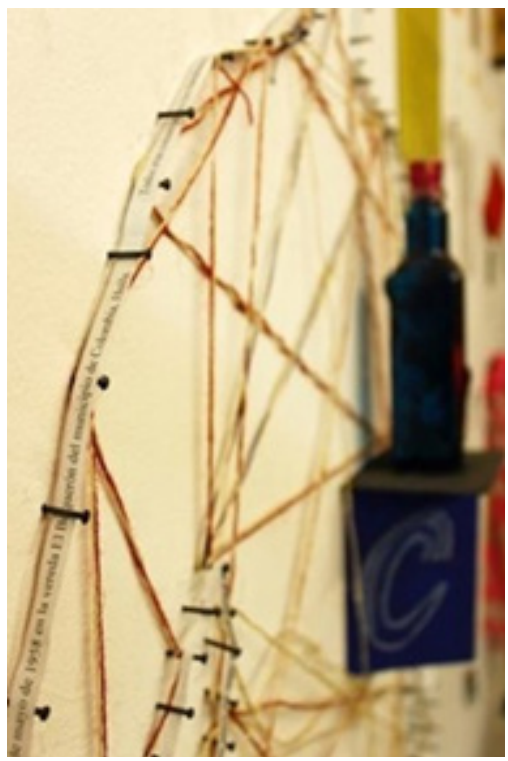

Figura 21:

Activadores del recuerdo: reproducción de botella 2. Fuente: elaboración propia.

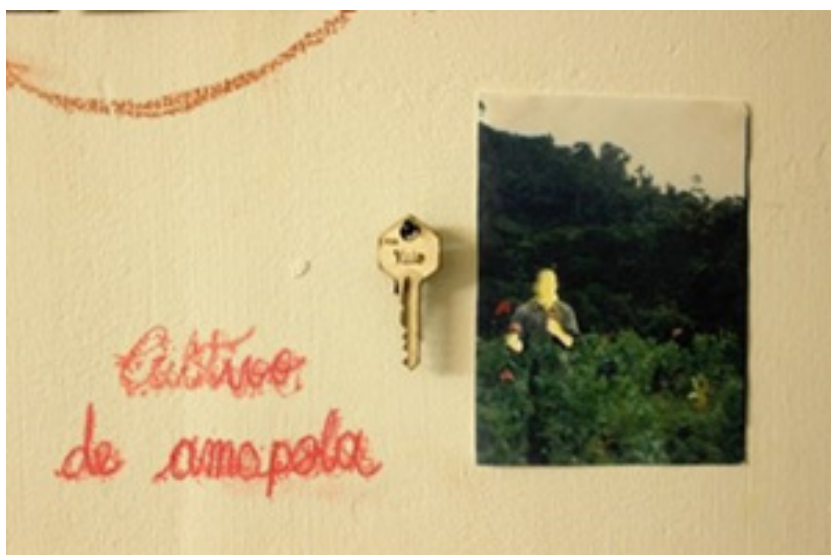

Figura 22:

Activadores del recuerdo: fotografía intervenida Fuente: elaboración propia.

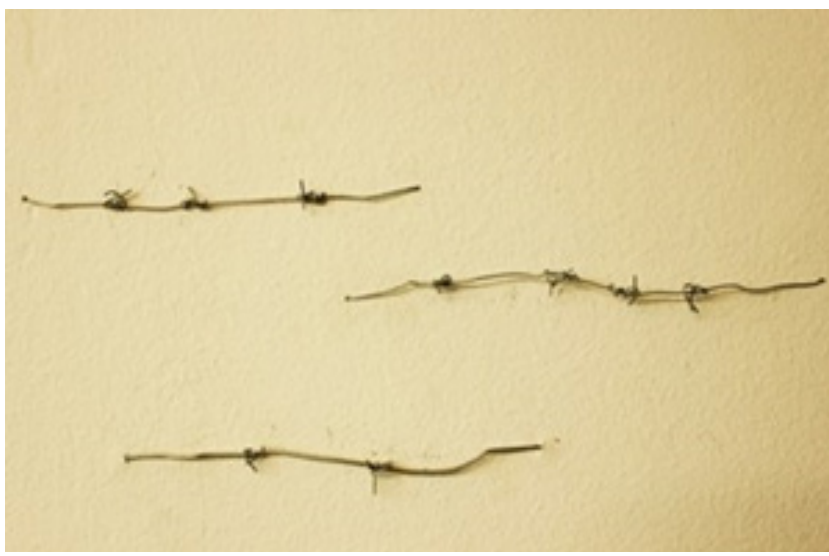

Figura 23:

Activadores del recuerdo: reproducción de cerca Fuente: elaboración propia.

Como ocurre con la abuela de Yuly, el conflicto armado del país, sobre todo en el contexto rural, es otra de las situaciones que marcan nuestras memorias y recuerdos. Cortés Severino (2009) habla de las memorias de la violencia, las cuales consisten en la elaboración cultural de la memoria a través de sus discursos, representaciones, significados y prácticas. Así, afirma:

[con] memorias de la violencia me refiero a cómo el sufrimiento provocado por actos violentos y de terror es el medio a través del cual se inscribe la memoria en cuerpos y lugares, es decir, la memoria como proceso corporal, emotivo y arraigado en prácticas cotidianas. (Cortés, 2009, p. 167)

Esta memoria ha estado presente en la familia de Carolany, víctima directa de las acciones adelantadas por grupos guerrilleros. A partir de las experiencias de su mamá, narra acciones que se relacionan con el asesinato y las amenazas, las cuales metaforiza con ceniza que recogió en su pueblo natal, Guaduas (Figura 9). Según ella: 
Mi mamá empezó a estudiar a la edad de 8 años, pero a mitad de año el profesor fue asesinado. La última vez, quemaron la escuela con el profesor dentro. Él gritaba y olía a carne quemada, pero nadie pudo hacer nada. (Comunicación personal, Carolany, 2018)

\section{Además de ello, afirma:}

El patrón no dejó el dinero y por eso mi abuelo apartó unas vacas para la guerrilla, para que no les hicieran nada a mi mamá, mis tías y mi tío, quienes se quedaron solos en la finca mientras él iba a buscar al patrón. Dejó instrucción de no salir si las vacas mugían, porque iban a ir a recoger a unas, - Escóndanse debajo de la cama y no salgan — dijo. No había nadie que los cuidara porque la mamá había muerto. Las reses empezaron a mugir, se escucharon disparos, mi tío se subió a la copa de un árbol y prendió una antorcha para pedir auxilio a los vecinos, quienes llegaron en grupo. En ese momento la guerrilla paró la matanza del ganado y se dirigió a la casa, pero un vecino habló con ellos e intercedió por los niños, abogando que estaban solos y se habían asustado. La guerrilla los dejó pasar, pero solo en esa ocasión. Al ganado lo mataron a disparos y machete, picaron a algunas vacas y se llevaron lo que pudieron, el resto quedó en el campo, pero como dieron órdenes de que la comunidad no las podía aprovechar, fue necesario enterrarlas para que no se descompusieran al aire libre. (Comunicación personal, Carolany, 2018)

Otro de los miedos que encontramos tiene que ver con acciones ubicadas temporal y socialmente en el contexto del narcotráfico que vivenció el país a inicios de la década de los noventa. Camila, que partió de una fotografía que retrata a sus padres y hermanas para hablar de su familia (Figura 25 y Figura 26), describe el miedo como consecuencia de los atentados en Bogotá D. C.:

Una fotografía familiar momentánea retrata una década de violencia en el país. Esta fotografía fue tomada en el patio de mi casa durante el año 93, allí se encuentra mi papá, mi hermana y un taxi que sólo se sacaba a producir de noche. Mi mamá acompañaba a mi papá todas las noches, mientras dejaban a mis hermanas en el lote, ellas se cuidaban la una a la otra. Era difícil tanto para mis papás como para mis hermanas estar a la espera de un nuevo día, porque no se sabía a qué hora llegaban o (en un caso peor) si no llegaban. El miedo de saber que, por esos tiempos, se colocaban explosivos por cualquier sector; además, se alimentaba el terror mediante el contenido televisivo, en las noticias sólo se mostraba: "se busca narcotraficante”. (Comunicación personal, Camila, 2018)

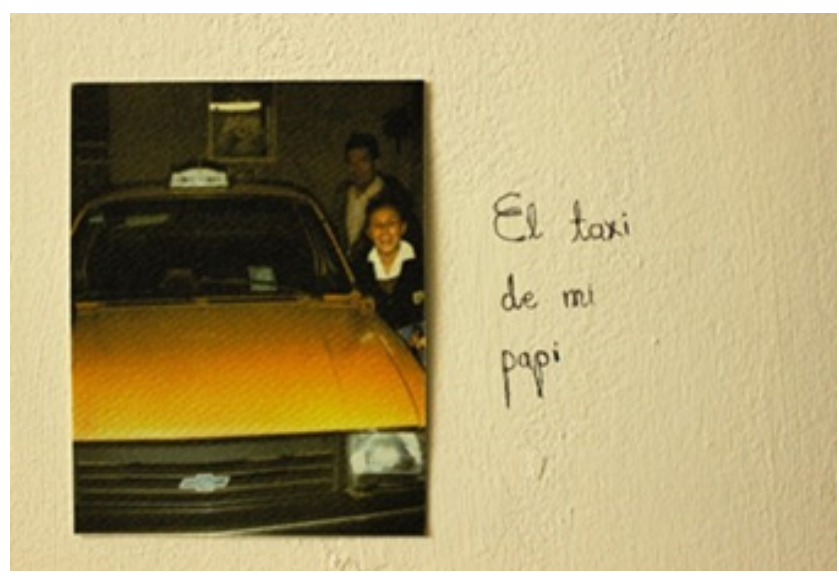

Figura 24: Activadores del recuerdo: fotografías del álbum familiar 2. Fuente: elaboración propia.

Relatar nuestro pasado familiar implica dar cuenta de unas relaciones entre vivencias personales que, en función del miedo como reacción a acciones dolorosas, se vinculan con contextos sociales que han marcado la historia de nuestro país. Por ello, atendemos al llamado que hace Cortés Severino (2007) para entender la historia, la memoria y el conocimiento, al nivel de la experiencia inmediata y de la subjetividad individual, donde la narración tiene agencia.

Sin duda, estas experiencias y subjetividades se sitúan en contextos y situaciones de violencia: el conflicto armado colombiano, el narcotráfico, la Violencia bipartidista y hasta las disputas por la fe. En este punto, cabe preguntarse: ¿cómo nuestros recuerdos, que en apariencia son aislados, pueden dar cuenta de unas memorias de la violencia (Cortés, 2009)?, ¿qué lugar tenemos, en tanto actores del pasado, para narrar, documentar, reflexionar y resignificar esa memoria desde las evocaciones de nuestros relatos y objetos?, ¿cómo las particularidades de nuestros contextos inmediatos nos permiten crear otras miradas sobre lo que nuestras familias recuerdan de la violencia en Colombia?, ¿cómo abordar el miedo para crear nuevas formas de entender ese pasado?

\section{Del entramado a las herencias familiares}

El acto de heredar tiene múltiples implicaciones por parte de quien transmite y quien recibe lo transmitido, teniendo ambos sujetos una responsabilidad de preservación sobre ese conocimiento intergeneracional. Según Jelin (2002) “En la vejez, muchos quieren 'transmitir', dejar algo de su experiencia a las generaciones posteriores” ( $p$. 120), con el propósito de que los saberes identitarios de una comunidad no mueran con una generación. Muchas veces estos saberes, oficios, actitudes o experiencias se transmiten desde un relato o se materializan en un objeto heredado, cargado de unas experiencias contenidas en la 
memoria de los propietarios.

Podríamos decir que nuestra cartografía de la memoria está poblada de transmisiones generacionales y que, como vimos, proviene de un pasado que se evoca desde recuerdos, olvidos y silencios, los cuales se relacionarían directamente con la naturaleza violenta de algunos de los hechos narrados que generaron transformaciones al interior de los colectivos, en algunos casos dolorosos, pero que aun así se transmiten a las nuevas generaciones. A esto lo podríamos llamar, desde Hirsch (2012), posmemoria, entendida como las relaciones que surgen entre las nuevas generaciones con el pasado de su colectivo, entretejiendo los pasados que en ocasiones están mediados por traumas, para que las nuevas generaciones se identifiquen desde la emotividad, pero con la distancia temporal que les permite acercarse desde una mirada crítica.

En relación con lo anterior, dentro del proceso de transmisión es necesario que "Las nuevas generaciones puedan acercarse a sujetos y experiencias del pasado como 'otros', diferentes, dispuestos a dialogar más que a re-presentar a través de la identificación” (Jelin, 2002, p. 120). Por eso, al construir un diálogo entre el pasado y el presente de un colectivo, se da paso a una adaptación o reinterpretación de lo heredado, según una visión del presente. Esto se demuestra en el relato de David, el cual deviene de una camisa que colocó, de forma fragmentada, en la cartografía (Figura 27 y Figura 28):

Una de las cosas que más recuerdo de mi abuelo, además de su sombrero verde, su ruana, su vestido de paño y sus zapatos negros que tenía que mandar a hacer, son sus camisas. Mi papá también usa camisas parecidas, sobre todo, las azules, como la de la cartografía: una camisa fragmentada, cuello, mangas y botones. También uso camisas, sobre todo las que tienen cuadros. Más allá de ponerme camisas como lo hace mi papá y como la hacía mu abuelo antes de morir, ¿qué es lo que heredo?, ¿qué cosas encuentro parecidas entre mi abuelo y mi papá? Hombres del campo, a veces machistas, fieles a sus esposas, trabajadores y campesinos, con el deseo de heredar su apellido. (Comunicación personal, David, 2018)

En el relato de David encontramos múltiples elementos que implican una herencia que se trasmite entre generaciones, poniendo en diálogo el pasado con el presente. Inicialmente, desde una característica de su vestimenta que se relaciona con dos generaciones de su familia, hace referencia a una identificación y diferenciación de la forma en que ha adaptado la transmisión generacional de lo masculino, en función de su presente y su contexto. Aunque parezca paradójico, "una transmisión lograda ofrece a quien la recibe un espacio de libertad y una base que le permite abandonar (el pasado) para (mejor) reencontrarlo" (Hassoun, 1996, p. 70). Dentro del diálogo con lo heredado, es posible evaluar las prácticas y actitudes que se podrían heredar y transmitir a las futuras generaciones o replantearlas en función de sus necesidades y contexto.

Siguiendo a Jelin (2000):

La transmisión entre quienes vivieron una experiencia y quienes no la vivieron, porque todavía no habían nacido, o porque no estaban en el lugar de los acontecimientos, o porque, aunque estaban allí, por la diferentes ubicación etaria o social, la experimentaron de otra manera. (p. 124)

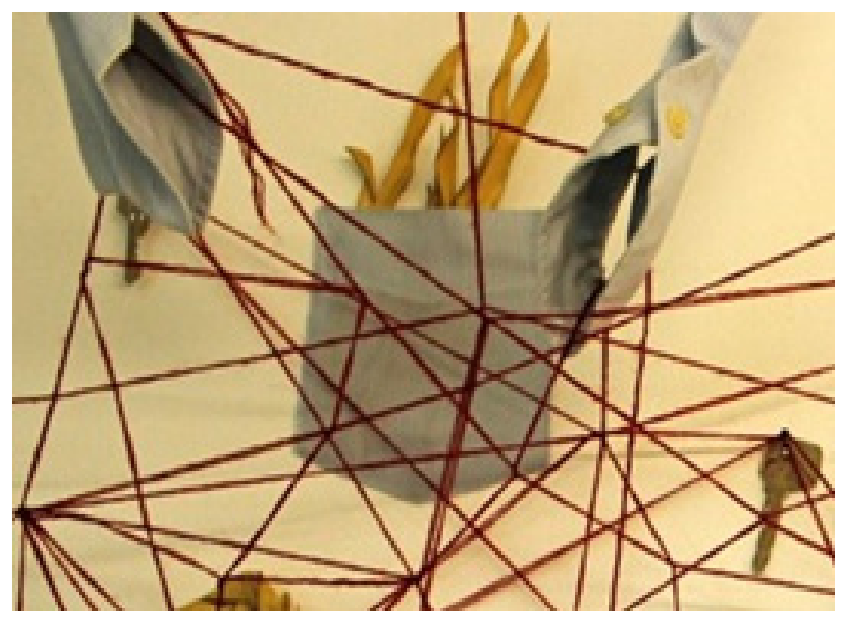

Figura 25: Camisa fragmentada 1 Fuente: elaboración propia.

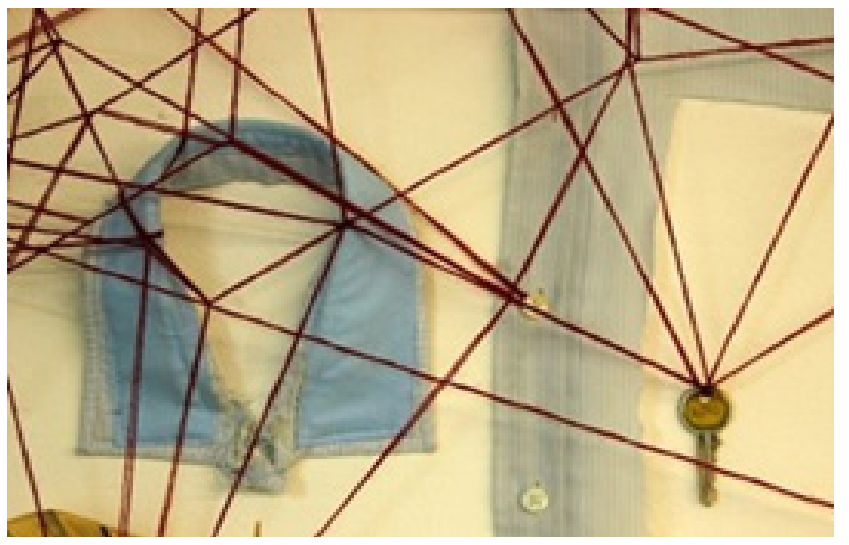

Figura 26: Camisa fragmentada 2 Fuente: elaboración propia.

Estas diferencias temporales y contextuales entre el que hereda y el heredero, influencia la visión frente a la experiencia, en relación con una serie de actitudes, el objeto o saber, como en el caso de David, quien construye el siguiente relato a partir de algunas huellas que recogió de la finca de su padre (Figura 29): 
Hace unos años fui a la finca de mi papá, está en medio del frío del altiplano cundiboyacense. Recogí semillas, hojas secas, piedras, pasto, flores, troncos... Así como la memoria, estas huellas se convierten en evidencias de mi recorrido, pero también de esa herencia campesina que mi papá todavía mantiene con tanto orgullo desde su oficio: ordeñar, sembrar, cercar, cocinar y todo lo que implica cuidar de su finca. Desde hace tiempo, mi mamá le ha insistido en que venda la finca, que ya está muy viejo y enfermo para ese trabajo tan duro. En el fondo, él no la quiere vender. (Comunicación personal, David, 2018)

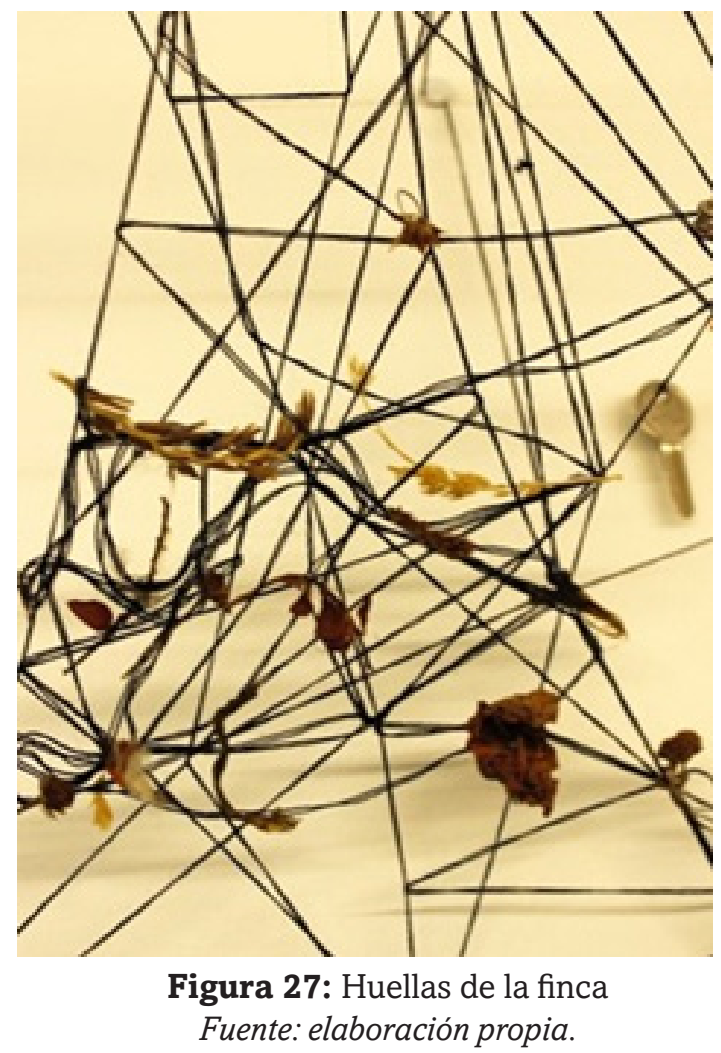

En este relato, identificamos una diferenciación entre las formas de relacionarse con la tierra, dado que la experiencia de recolección que narra David se diferencia de la experiencia de su padre alrededor de un oficio que tiene como propósito el cuidado y preservación. Podemos decir que la experiencia de su padre frente al cuidado de la tierra y su resistencia a vender se relaciona con el hecho de que esta tierra es una transmisión generacional que implica unas costumbres y actitudes, que él recibió en un momento de su vida y que, en otro, como afirma David, probablemente le herede a sus hijos y ellos hereden a nuevas generaciones, manteniendo o modificando el legado de su familia. Transmitir, entonces, es ofrecer a las generaciones posteriores un saber-vivir (Hassoun, 1996).

En los relatos de David, y como una constante en la cartografía, encontramos lo rural como un escenario donde se hacen presentes los acontecimientos que marcan nuestras memorias familiares. A diferencia de David donde lo heredado - a primera vista - no tiene que ver con hechos violentos, cabe la pregunta por cómo el pasado es transmitido cuando se habla del conflicto armado, particularmente, desde aquellos silencios que podrían negar "herencias dolorosas" a nuestra generación. Así, todos los recuerdos, pero también los olvidos y silencios que señalamos desde los relatos y los objetos, son una herencia transmitida desde la oralidad y desde la materialidad de las cosas (vehículos evocativos). Estas experiencias transmitidas median las formas en que hemos construido nuestra existencia y habitamos el ahora.

\section{A modo de conclusión, o mejor, "Del porqué de la memoria"}

A partir de nuestra experiencia cartográfica desplegada en objetos, narrativas y reflexiones teóricas, podemos decir que los recuerdos emergieron como indicio de que algo pasó en las memorias familiares, sin mostrar o expresar directamente el suceso. Hablar sobre el objeto en muchos casos nos llevaba a alguna parte del relato, también a recordar a la persona o personas (ausentes en algunos casos) que tuvieron lugar en la memoria, que fueron protagonistas o quienes relataron. Así, se empezaron a poner los primeros objetos en la pared que, desde los relatos, se fueron entrelazando para construir "una guía" de ubicación de los objetos que llegaron después.

La experiencia de las familias y la memoria que todo el tiempo navegó en y a través de la cartografía, operó desde una compleja red de relaciones que tensionaba recuerdos, silencios y ausencias individuales (en este caso de nosotros y de nuestros parientes) para luego darse a un relato más amplio que se hacía colectivo para los y las integrantes del semillero. Sin duda las ausencias en nuestra memoria, que a veces estaban vinculadas con memorias de la violencia, las reconocimos como interiorizadas en el presente en formas inesperadas, por ejemplo, en el medio vivido o que nos fue transmitido.

Así como aparece una "resistencia a vender la tierra" en una de las narrativas, nuestra cartografía se nos muestra como resistencia a no olvidar el pasado, no desde una perspectiva acumulativa, sino desde una perspectiva reinterpretativa, desde la experiencia presente de quien recuerda.

Este proceso no tendría sentido sin los espacios de diálogo y de construcción colectiva entre los integrantes del grupo. Al recordar colectivamente, nos hicimos conscientes de que nuestras memorias están enlazadas, lejos del pensamiento ilusorio de que la violencia no nos ha tocado a todos. Al encontrarnos para relatar, nos dimos cuenta de que la memoria colectiva en Colombia, en relación con la violencia, termina uniéndonos, paradójicamente, a partir de un sentimiento de miedo colectivo que ha movilizado al país durante décadas. 
Ese miedo, como el eje movilizador de los sujetos y situaciones que aquí se narran, termina poniendo en tela de juicio la consideración de la verdad al relatar de manera objetiva el pasado. Un testimonio desencadenado por el miedo, termina siendo, en palabras de Jelin (2002), una narrativa subjetivada, dado que la consideración de la verdad se desplaza a la descripción de los hechos desde quien los ha sufrido a partir del dolor. En este sentido, se desata una lucha por la legitimidad y el poder sobre el discurso de los hechos, donde cada parte, víctima y actor, busca el reconocimiento de su propia versión desde aquello que a cada uno afecta.

Así pues, con nuestra cartografía reconocimos una memoria colectiva que tiene su punto de encuentro en el papel de las víctimas, donde se evidencia un consenso en el momento histórico de la violencia en Colombia. Aquí, se da voz a las memorias individuales de nuestras familias, microrrelatos que lejos de ser historias hegemónicas y validadas por instituciones como el Estado o la Iglesia, buscan que desde nuestros contextos cotidianos se creen discursos particulares, en un ejercicio de "resistencia" que se aleja de las versiones oficiales y los medios masivos.

Este ejercicio de reconstrucción de memoria, a partir los objetos desde su materialidad y su función como vehículos de la memoria, permiten sacar del silencio y el olvido colectivo aquellos sucesos que marcaron la vida de nuestras familias de una manera significativa, dando visibilidad a unos hechos que se resignifican a partir de las voces de nuevos actores - o generaciones-y a la luz de las circunstancias históricas del presente.

El hecho de recordar, pero también olvidar y callar, para reinterpretar el pasado desde unas situaciones específicas que abarcan la historia del país, conlleva unas implicaciones políticas a partir de las memorias individuales. Desde allí, es posible repensarse el pasado desde las circunstancias históricas y políticas del presente para proyectar un futuro personal y social. Esto es lo que Vázquez (2001) propone como continuidad social, pues la memoria no es otra cosa que la reinterpretación el pasado desde la creación de significados móviles, según las necesidades del presente, donde lo reconstruido se proyecta hacia el futuro, garantizando la existencia de la sociedad.

Lo anterior también lo podemos comprender desde Hirsch (2012) y su concepto de posmemoria. Al crearse una serie de relaciones intergeneracionales que se permean mutuamente desde la construcción de memoria se hace presente la crítica que puede generar diferentes transformaciones en la percepción del presente y la construcción del futuro. Por ello, desde nuestro lugar temporalmente distante a los pasados de nuestras familias, estamos en obligación resignificar y generar críticas sociales, en nuestro caso desde procesos creativos.

De esta manera, podemos dar cuenta de una experiencia de transformación en nuestras subjetividades, en tanto semilleristas desde varios lugares. Primero, tomamos distancia sobre los modos de relacionarnos con nuestras familias y las memorias que las configuran; por ello, se complejizó, problematizó y amplió una identidad familiar y el relato que la arma temporal y espacialmente. Por otro lado, como sujetos de la evocación, comprendimos que narrar el pasado, además de hacerse de manera fragmentada y parcial, implica reconocer lo invisible, lo que permanece al margen del recuerdo; en nuestro caso, logramos delimitar una memoria dolorosa, cargada de miedo, y a veces de resentimiento, para abrir caminos a una reconciliación con ese pasado.

Otra de las transformaciones que logramos identificar como sujetos, tiene que ver con nuestra implicación directa a un problema de investigación, que en este caso también se vinculó con un ejercicio de creación colectiva. Reconocernos como sujetos que recuerdan, olvidan, callan y heredan del pasado familiar y social nos permitió romper con las fronteras entre subjetividad y objetividad que muchas veces se polarizan en la construcción de conocimiento. Además de ahondar en nuestra experiencia sensible y personal con el pasado a partir de lo particular (elementos que muchas veces son descartados por la tradición disciplinar heredada de la modernidad), construir nuestra cartografía implicó situarnos desde y con lo otro mediante el relato, esto es, enunciarnos desde la intersubjetividad.

Las circunstancias presentes en las que tiene lugar el pasado reconstruido parecen ser las que posiblemente incitan al recuerdo a salir de sus silencios, despertado por un nuevo miedo que se resiste a no repetir la historia. En palabras de Jelin (2002), el ejercicio de la memoria en los contextos conflictivos, tiene el objetivo de "superar los olvidos y los abusos políticos, tomar distancia y al mismo tiempo promover el debate y la reflexión activa sobre ese pasado y su sentido para el presente/futuro" (p. 16).

En tal sentido, nuestra cartografía de la memoria, en tanto estrategia metodológica, se presenta como un aporte a la construcción colectiva de escenarios reflexivos sobre el pasado y las formas de legitimarlo en contextos particulares. Este tipo de narrativas situadas nos enfrentan a retos para tensionar e irrumpir en los grandes relatos históricos o de la memoria oficial que, construida por los intereses institucionales mediante dispositivos como los medios de comunicación, desconocen la experiencia subjetiva de las memorias. Sin duda las cartografías permiten vislumbrar posibilidades para resignificar y narrar de modos diferentes ese pasado, con una perspectiva crítica y acorde a los contextos y la maleabilidad del tiempo. 


\section{Referencias}

Arfuch, L. (2010). El espacio biográfico. Dilemas de la subjetividad contemporánea. Fondo de Cultura Económica.

Bauman, Z. (2007). Miedo líquido. La sociedad contemporánea y sus temores. Paidós.

Baudrillard, J. (1969). El sistema de los objetos. Siglo XXI Editores.

Candau, J. (2006). Antropología de la memoria. Ediciones Nueva Visión.

Cortés Severino, C. (2007). Escenarios de terror entre esperanza y memoria: políticas, éticas y prácticas de la memoria cultural en la Costa Pacífica colombiana. Antípoda. Revista de Antropología y Arqueología, 4, 163-186. https://doi.org/10.7440/antipoda4.2007.08

Cortés, C. (2009). Recolecciones sonoras y visuales de escenarios de memorias de la violencia. Antípoda. Revista de Antropología y Arqueología, 9, 165-197. https://doi.org/10.7440/antipoda9.2009.06

Didi-Huberman, G. (2010). ¿Cómo llevar el mundo a cuestas? TF Editores.

Guasch, A. (2005). Los lugares de la memoria: El arte de archivar y recordar. Materia, 5, 157-183.

Guasch, A. (2010). Arte y archivo, 1920-2010. Genealogías, tipologías y discontinuidades. Akal.

Guridi, R. y Tartás, C. (2013). Cartografías de la memoria. Aby Warburg y el Atlas Mnemosyne. EGA Expresión Gráfica Arquitectónica, 18(21), 226-235. https:// doi.org/10.4995/ega.2013.1536

Halbwachs, M. (2004a). Los marcos sociales de la memoria. Anthropos.

Halbwachs, M. (2004b). La Memoria Colectiva. Prensas Universitarias de Zaragoza.

Hassoun, J. (1996). Los contrabandistas de la memoria. Ediciones de la Flor.

Hirsch, M. (2012). La generación de la posmemoria. Escritura y cultura visual después del Holocausto. Carpe Noctem.

Jaramillo, L. (2006). Ser sujeto en la investigación: investigando desde nuestra subjetividad. Revista Colombiana de Educación, (50), 104-118.

Jelin, E. (2002). Los trabajos de la memoria. Siglo XXI Editores.

Mendoza, J. (2005). La forma narrativa de la memoria colectiva. Polis, 1(1), 9-30.

Ramos, D., López, L., Solano, L., Ramírez, J., Beltrán, H. y Díaz, W. (2018). La memoria y su devenir en los espacios: evidencias del pasado en algunas experiencias cartográficas. (pensamiento), (palabra). Y Obra, (20). https://doi.org/10.17227/ppo.num20-8158

Vasilachis, I. (2006). La investigación cualitativa. En: I. Vasilachis (Coord.). Estrategias de investigación cualitativa. (26-64). Gedisa.

Vázquez, F. (2001). La Memoria como Acción Social: relaciones, significados e imaginario. Paidós. 